\title{
Murabaha Finansmanı Yönteminin Türkiye Muhasebe Standartları ve Faizsiz Finans Muhasebe Standartları Kapsamında Katılım Bankaları Açısından Muhasebeleştirilmesi: Karşılaştırmalı Bir Örnek Uygulama*
}

\section{ÖZET}

Bu çalışmanın amacı faizsiz finansman yöntemlerinden biri olan murabaha finansman yöntemini ihtiyaca ve gerçeğe uygun sunum noktasında Kaти Gözetim Kurumu (KGK) tarafindan yayılanan Türkiye Muhasebe Standartları (TMS) ve Faizsiz Finans Muhasebe Standartları (FFMS) açısından karşılaştırmak suretiyle farklılıkları ve sorunları ortaya koymak ve bu doğrultuda çözüm önerileri sunmaktır. Çalışmada, murabaha finansmanı yöntemiyle ilgili Türkiye Muhasebe Standartları ve Faizsiz Finans Muhasebe Standartları incelenmiş ve muhasebe ilkeleri ortaya konularak Bankacılık Düzenleme ve Denetleme Kurumu (BDDK) tarafindan katılım bankaları için yayınlanan tek düzen hesap planı doğrultusunda muhasebeleştirilmesi sağlanmıştır. Çalışmanın sonucunda her iki düzenleme arasında özün önceliği ve hukuki öncelik noktasında farklılık olduğu ortaya konmuștur. Buna göre Faizsiz Finans Muhasebe Standartları bir işlemin hukuki yönünü öncelerken, Türkiye Muhasebe Standartları bir işlemin ekonomik özünü öncelemektedir. Bu durum murabaha konusu malların stok olarak izlenmesinde her iki standart arasinda farklllk ortaya çıkarmaktadır. Buna bağlı olarak, murabaha finansmanının Faizsiz Finans Muhasebe Standartlarına göre muhasebeleştirilmesi durumunda, söz konusu hesap planında bazı güncellemeler yapılması gerekmektedir.

Anahtar Kelimeler: Finansal Muhasebe, Türkiye Muhasebe Standartları, Faizsiz Finans Muhasebe Standartlarl, Murabaha Finansmanı, Katılım Bankaları.

JEL Sintflandirmast: G21, M40, M41.

Accounting Of Murabaha Financing Method By Participation Banks in Accordance with Turkey Accountıng Standards (Tas) and Interest-Free Finance Accounting Standards (IFFAS): A Comperative Example

\section{ABSTRACT}

The aim of this study, at the point of relevance and fair presentation, by revealing differences between them, to provide solutions to the problems for accounting of the murabaha financing method which is one of the interest-free financing methods according to Turkey Accounting Standards and Interest-Free Finance Accounting Standards, which both are published by the Public Oversight Board (the KGK). In the study, the accounting standards of Turkey Accounting Standards and Interest-Free Finance Accounting Standards related to murabaha financing were examined and provided accounting transaction accordance with the uniform chart of accounts issued by Banking Regulation and Supervision Board (The BDDK) by revealing accounting principles of murabaha. The study revealed that the difference between both these regulations at the point of form versus substance. So, while Interest-Free Finance Accounting Standards receive legal form a transaction, Turkey Accounting Standards economic receive substance of a transaction. Thus, in case the murabaha financing is accounted to the Interest-Free Finance Accounting Standards, some updates are required in the said uniform chart of accounts.

Keywords: Financial Accounting, Turkey Accounting Standards, Interest-Free Finance Standards, Murabaha Financing, Participation Banks.

Jel Classification: G21, M40, M41.

\footnotetext{
* Makale Gönderim Tarihi: 12.10.2020, Makale Kabul Tarihi: 30.11.2020, Makale Türü: Kuramsal Makale

** Arş. Gör. Dr., Finans ve Bankacılık Bölümü, Uygulamalı Bilimler Fakültesi, Manisa Celal Bayar Üniversitesi, ayhan.yatbaz@cbu.edu.tr (Sorumlu Yazar), ORCID: 0000-0002-6059-4176.

*** Prof. Dr., Sigortacılık Bölümü, Bankacılık ve Sigortacılık Yüksekokulu, Marmara Üniversitesi, ozgurcatikkas@yahoo.com, ORCID: 0000-0002-7774-5882.
} 


\section{GIRIŞ̧}

Murabaha lügat anlamı "artma, kâr, ticarî kazanç" olan "ribh” kökünden türemiş olup "kazandırma, kâr hakkı tanıma" anlamına gelmekte olup terim olarak ise bir malın alış fiyatı veya maliyeti üzerine belirli bir kâr konarak satılmasını ifade eder (TDV, 2016). İki çeşit murabaha söz konusudur. Birincisi klasik murabaha olup taraflar arasında doğrudan bir alım satım işlemine dayanır. Bu işlem satıcı tarafından ilk fiyatın ve kâr oranının söylenmesi üzerine gerçekleşir. İkincisi ise modern murabaha olup esas alıcının nakit gereksinimi sebebiyle finansman kullanarak tutarı taksitle geri ödemesi üzerine dayanır (Cebeci, 2010: 3839). Murabaha faizsiz bankalar (katılım bankaları) tarafindan en yaygın kullanıma sahip finansman sözleşmelerinden biridir (Zarfi, 2019: 23). Aynı şekilde Türkiye'deki katılım bankalarının da en çok kullandığı fon kullandırma yöntemlerinden biridir. Türkiye Katılım Bankaları Birliği (TKBB) verilerine göre 30 Haziran 2020 itibarıyla katılım bankalarınca kullandırılan toplam fon yaklaşık olarak 140 milyar TL düzeyinde olup bunun yaklaşık olarak \%97'si murabaha finansmanıyla kullandırılmıştır.

1990 yılında kurulan Bahreyn merkezli uluslararası özerk bir kuruluş olan İslami Finansal Kuruluşlar Muhasebe ve Denetim Organizasyonu (Accounting and Auditing Organization for Islamic Financial Institutions-AAOIFI) murabaha finansmanı işlemiyle birlikte faizsiz finans alanında birçok konuyu Şer'i Standartlar adıyla düzenleme altına almıştır. Türkiye Katılım Bankaları Birliği (TKBB) tarafından 2018 yılında "Faizsiz Finans Standartları (FFS)" adıyla Türkçeye çevrilerek yayınlanan bu standartlar Türkiye'de uygulanma zorunluluğu bulunmamakla birlikte bir rehber görevi görmektedir. Murabaha konusunun düzenleme altına alındığ "FFS 8 Murabaha" standardına göre murabaha işlemi bir kimsenin satın almış olduğu malı, alış bedeli üzerine anlaşılan tutarda belirli bir kâr ilave ederek satmasıdır. Murabaha işleminin İslamiyet'in ilk yıllarında da görülen bu hali klasik murabaha olarak adlandırılır. Taraflar arasında işlem öncesinde satın alma ve satma vaadi üzerine kurulan günümüz murabaha sözleşmeleri ise çağdaş murabaha olarak adlandırılmaktadır. Başka bir ifadeyle çağdaş murabaha faizsiz finans kurumu (katılım bankası) aracılığıyla mal veya hizmet satın almak isteyen müşteri ile katılım bankası arasında satın alma vaadi üzerine kurulan murabaha sözleşmesidir. Bu işlemde katılım bankası satın almış olduğu malı, alış fiyatı veya maliyeti üzerine vaat aşamasında üzerinde anlaşılan tutarda kâr (murabaha kârı) ilave ederek satmaktadır.

AAOIFI sadece faizsiz finansal kuruluşlara yönelik olmak üzere, "Şer’i Standartlar"ın yanında finansal muhasebe standartları, denetim standartları, yönetişim standartları ve etik standartları da yayınlamaktadır. AAOIFI muhasebe standartlarının yanında diğer alanlarda da standart yayınlama özelliği bakımdan Uluslararası Muhasebe Standartları Kurumu'ndan (International Accounting Standard Board-IASB) ayrılmaktadır. IASB, AAOIFI'nin aksine bütün sektör ve ürünleri kapsamak üzere sadece muhasebe ve finansal raporlama alanında standartlar yayınlamaktadır.

IASB tarafindan yayınlanan Uluslararası Muhasebe Standartları (International Accounting Standards-IAS) ve Uluslararası Finansal Raporlama Standartları (International Financial Reporting Standards-IFRS) Türkiye'de bir kamu kurumu olan Kamu Gözetimi Muhasebe ve Denetim Standartları Kurumu (KGK) tarafından Türkiye Muhasebe Standartları (TMS) ve Türkiye Finansal Raporlama Standartları (TFRS) adıyla Türkçeye çevrilmekte ve yayınlanmaktadır. TMS/TFRS'ler Türkiye'de katılım bankaları da dahil olmak üzere kamu 
yararını ilgilendiren kuruluş kapsamına giren tüm kuruluşlar tarafından uygulanmak zorundadır.

IASB muhasebe ve finansal raporlama düzenlemeleri tüm sektör ve ürünleri kapsayacak şekilde düzenlenmekle birlikte faizsiz finans kuruluşları ve ürünlerinin ihtiyacını tam olarak karşılamadığ 1 gerekçesiyle AAOIFI tarafından "Finansal Muhasebe Standartları" adıyla ayrı bir muhasebe düzenlemesi yapılmıştır. KGK tarafından Türkiye'de Faizsiz Finans Muhasebe Standartları (FFMS) adıyla yayınlanan bu standartlar ihtiyaca ve gerçeğe uygun sunum noktasında sadece faizsiz finans kurumları ve ürünlerine yönelik çözüm sunmaktadır. AAOIFI'nin ayrı bir muhasebe düzenlemesi yapmasının nedeni olarak, IASB muhasebe düzenlemelerinin aşağıda belirtilen bazı noktalarda faizsiz finans kurumları ve ürünlerine yönelik ihtiyaca ve gerçeğe uygun sunumu sağlamada yetersiz kalması gösterilebilir:

IASB muhasebe standartlarına göre bir işlemin öncelikle ekonomik özü dikkate alınmakta, hukuki yönü ikinci planda tutulmaktadır. Bu bakış açısıyla İslam dinine göre satış işlemi ya da ticari ortaklık olarak görülen birçok işlem, IASB tarafından bir kredi kullandırma işlemi olarak görülmektedir (Maurer, 2010: 33).

IASB muhasebe standartlarına göre gider ve gelirlerin muhasebeleştirilmesinde tahakkuk esası dikkate alınmaktadır. Nakit esasının göz ardı edilmesi İslam dininde farz bir ibadet olan Zekâtın muhasebe ve raporlama konusunu zorlaştırmaktadır.

IASB'ye göre finansal tablo unsurları varlık, borç, özkaynak, gelir ve gider olmak üzere beş tanedir. Bu durum, faizsiz finans kuruluşlarının en yaygın fon toplama yöntemlerinden biri olan katılma (yatırım) hesaplarının raporlanmasıyla ilgili sorun oluşturmaktadır. Çünkü katılma hesapları kâr ve zarara katılma hakkı vermekle birlikte faizsiz finans kurumunun özkaynak unsuru ya da borç unsuru kapsamına girmemektedir. $\mathrm{Bu}$ bakımdan borç ve özkaynaktan farklı olarak ayrı bir finansal tablo unsuruna ihtiyaç duyulmaktadir.

AAOIFI, IASB'den farklı olan bir diğer yönü de faizsiz finansal ürünlere özgü standartlar yayınlamasıdır. Bu standartlardan biri de çalışmanın konusu oluşturan murabaha finansmanı işlemiyle ilgilidir. KGK tarafından FFMS 28 Murabaha ve Diğer Vadeli Satışlar adıyla yayınlanan bu standardın amacı alıcı ve satıcı tarafından murabaha ve diğer vadeli satış işlemlerinde uygulanacak finansal tablolara alma, ölçüm ve açıklamalara ilişkin uygun muhasebe ve raporlama esaslarını belirlemektir. Buna karşılık TMS/TFRS'ler murabaha konusunda herhangi bir spesifik düzenleme sunmamakla birlikte, uygulamada kredi ve kredi benzeri işlemler için kullanılan standartlar özün önceliği ilkesinden hareketle murabaha işlemine de uygulanmaktadır.

$\mathrm{Bu}$ çalışmanın amacı, faizsiz finansman yöntemlerinden biri olan murabaha finansmanı yönteminin ihtiyaca ve gerçeğe uygun sunumunun sağlanması noktasında, FFMS ve TMS/TFRS'ler açısından farklılıkları ortaya koymak ve çözüm önerileri sunmaktır. Çalışmada öncelikle "Faizsiz Finans Standartları (FFS) 8 Murabaha" standardından ve ilgili literatürden hareketle murabaha finansmanı yönteminin işleyişi açıklanmış ve murabahanın Türkiye'deki uygulaması ortaya konulmaya çalışılmıştır. Ardından murabaha işleminin hem satıcı hem alıcı açısından muhasebeleştirme ve finansal raporlama ilkeleri "FFMS 28 Murabaha ve Diğer Vadeli Satışlar" standardı ve ilgili TMS/TFRS'ler esas alınarak açıklanmaya çalışılmıştır. Daha sonra ise murabaha finansmanıyla ilgili olarak Türkiye'deki bir katılım bankasının finansman hesaplama motorundan yararlanarak geliştirilen bir örnek 
uygulama yardımıyla FFMS ve TMS/TFRS'ye uygun olarak ayrı ayrı muhasebe işlemlerine yer verilmiştir.

\section{LITERATÜR TARAMASI}

Murabaha finansmanı ve özellikle muhasebeleştirilmesi güncelliğini koruyan bir konudur. Bununla birlikte Türkiye'de bu alanda yapılan akademik çalışmalar çok sınırlıdır. $\mathrm{Bu}$ çalışmalar aşağıdaki gibidir.

Yardımcıoğlu, Coşkun ve Kocamaz (2012) murabaha finansmanının ve bu kapsamda yapılan kâr payı ödemelerinin TMS 23 Borçlanma Maliyetleri standardına göre müşteri açısından muhasebeleştirilmesini yapmışlardır. Çalışmada özellikli varlıkların edinilmesi sırasında murabaha finansmanında yararlanılması durumunda katlanılan kâr payı giderlerinin varlığın maliyetine eklenebileceği ifade edilmektedir.

Antepli (2020) murabaha sukuk ihracını TMS 23 Borçlanma Maliyetleri standardı kapsamında incelemiş ve bir üretim işletmesin üzerine geliştirilen örnek uygulamayla açıklamıştır. Örneğin uygulanmasında Maliye Bakanlı̆ı̆nca 26.12 .1992 tarihli ve 21447 mükerrer sayılı Resmî Gazetede yayımlanan "1 Seri Nolu Muhasebe Sistemi Uygulama Genel Tebliği" esas alınmıştır.

Özkan (2012) katılım bankacılığı ile klasik bankaları muhasebe uygulamaları bakımdan karşılaştırmıştır. Günümüz katılım bankalarında kurumsal finansman desteği ya da bireysel finansman desteği adıyla karşılık bulan murabaha finansmanın işleyişi açıklanmış ve klasik bankalarda muadili olarak kabul edilen kredilerle arasındaki farklılıklar ortaya konmuştur. Çalışmanın uygulama kısmında Bankacılık Düzenleme ve Denetleme Kurumu (BDDK) tarafından katılım bankaları için yayınlanan tek düzen hesap planı doğrultusunda murabaha finansmanının muhasebe kayıtları yapılmıştır. Ancak çalışmada AAOIFI finansal muhasebe standartlarından söz edilmemiştir.

Aydoğmuş (2019) Albaraka Türk Katılım Bankası örneğinden yola çıkarak, Türkiye Muhasebe Standartları (TMS) ve Faizsiz Finans Muhasebe Standartları kapsamında murabaha finansmanının finansal raporlardaki sunumu konusunu incelemiştir. Çalışmada TMS'ye göre özün önceliği esası bakımından murabaha finansmanının normal bir kredi işlemi, FFMS'ye göre ise hukuki şekil öncelendiği için bir satış işlemi olarak kabul edildiği ortaya konmuştur.

Çebi ve Ünkaya (2018) murabaha sukuk modelinin Türkiye'deki uygulaması ve muhasebeleştirilmesi konusunu kaynak kuruluş, varlık kiralama şirketi ve yatırımcı açısından incelemişlerdir. Muhasebeleștirme konusunda Maliye Bakanlığınca 26.12.1992 tarihli ve 21447 mükerrer sayılı Resmî Gazetede yayımlanan "1 Seri Nolu Muhasebe Sistemi Uygulama Genel Tebliği” esas alınmıştır.

Eldelekli (2019) murabaha sukuk modelinin Türkiye'de uygulamas1 ve muhasebeleştirilmesi konusunu ele aldığı çalışmasında, Faizsiz Finans Muhasebe Standardı 28 Murabaha ve Diğer Vadeli Satışlar standardını esas alarak öncelikle ilk kez finansal tabloya alma, ilk ölçüm ve sonraki ölçümler, finansal tablo dışı bırakma gibi konulardaki muhasebe ilkelerini ortaya koymuştur. Muhasebeleştirilme işlemi kaynak kuruluş, varlık kiralama şirketi ve yatırımcılar açısından Maliye Bakanlığınca 26.12.1992 tarihli ve 21447 
mükerrer sayılı Resmî Gazetede yayımlanan “1 Seri Nolu Muhasebe Sistemi Uygulama Genel Tebliği’” esas alınarak yapılmıştır.

Bilindiği üzere modern anlamda murabaha işlemleri katılım bankalarınca yürütülmektedir. Dolayısıyla murabaha sukuk ihracına da bu bankalar kaynaklık etmektedir. Katılım bankaları Bankacılık Düzenleme ve Denetleme Kurumuna (BDDK) bağlı kuruluşlardır. Bu bakımdan esas alınacak hesap planının BDDK tarafından 26.01.2007 tarihli ve 26415 Mükerrer sayılı Resmi Gazete'de yayınlanan "Katılım Bankalarınca Uygulanacak Tekdüzen Hesap Planı ve İzahnamesi Hakkında Tebliğ" olmalıdır. Diğer taraftan varlık kiralama şirketleri de Sermaye Piyasası Kurulu (SPK) hükümlerine bağlı sermaye piyasası kuruluşlarıdır. Dolayısıyla bu kuruluşların muhasebe işlemlerinde ise 13.6.2013 tarihli ve 28676 sayılı Resmî Gazete'de yayınlanan "Sermaye Piyasasında Finansal Raporlamaya İlişkin Esaslar Tebliği (II-14.1)" hükümleri çerçevesinde SPK düzenlemeleri esas alınması gerekir.

Murabahanın muhasebe ve finansal raporlamasıyla ilgili Türkiye dışında yapılan çalışmalar ise genel olarak aşağıda belirtildiği gibidir.

Ilter ve ElBarrad (2012) murabaha konusunu "Pakistan Genel Kabul Görmüş Muhasebe İlkeleri" ve "Uluslararası Finansal Raporlama Standartları"na karşılık, Pakistan'ın kendi düzenlemesi olan "Murabaha Muhasebe Standardı" bağlamında ele almıştır. Çalışmada "Pakistan Genel Kabul Görmüş Muhasebe İlkeleri" ve "Uluslararası Finansal Raporlama Standartları"na göre stokların dönem sonu ölçümünün "maliyet ve net gerçekleşebilir değerin düşük olanı" yöntemine göre yapıldığı belirtilmiştir. Buna karşılık murabaha işleminde müşteri malı bankadan piyasa fiyatının üzerinde bir fiyattan aldığı için, ilk kayda almanın net gerçekleşebilir değerin üzerinde bir tutardan gerçekleştiğini ortaya koymuşlardır. Bankanın aracılığından kaynaklanan bu farkın aynı zamanda "Uluslararası Muhasebe Standardı 23 Borçlanma Maliyetleri” standardıyla da çatıştığı belirtilmiştir. Nitekim söz konusu standarda göre borçlanma maliyetleri sadece özellikli varlıklar söz konusu olduğunda maliyet unsuru olabilmektedir. Oysa stok olarak değerlendirilen murabaha konusu malı özellikli varlık olarak ele alınamayacağı dolayısıyla borçlanma maliyetlerinin ilave edilemeyeceğini belirtmişlerdir.

Rosman vd. (2016) murabaha işlemini IASB ve AAOIFI açısından ele almıştır. Çalışmada AAOIFI'nin murabaha ile ilgili spesifik bir standardının bulunduğu, buna karşılık IASB'nin bu konuda herhangi bir standardının bulunmadığı belirtilmiştir. Çalışmada Malezya Muhasebe Standartları Kurumunun (MASB) Şer'i ilkelerin geleneksel muhasebe standartları (IFRS ve GAAP) ile çatışmayacağı sonucuna vardığı, ayrıca IASB'nin 2011 yılında Şer'i Uyumlu Finansal Araç ve İşlemler Danışma Kurulunu kurarak İslami finansal işlemlerin finansal raporlamasıyla ilgili konuları tartıştığı konularına değinilmiştir.

Zarfi (2019) Fas’taki katılım bankalarının murabaha işlemlerini AAOIFI standartlarıyla karşılaştırmalı olarak incelemiştir. Karşılaştırma sonunda sunum ve açıklama, net gerçekleşebilir değer, murabaha sözleşme maliyetleri, iskonto ve diğer garantiler noktasında farklilar olduğunu ortaya koymuştur. 


\section{MURABAHA FINANSMANI YÖNTEMI VE İŞLEYIŞ̧i}

AAOIFI'nin tanımına göre murabaha, bir kimsenin satın almış olduğu malı, alış fiyatı üzerine anlaşılan tutarda kâr koyarak satmasıdır. Anlaşılan kâr tutarı, mal bedelinin belirli bir yüzdesi olabileceği gibi maktu bir tutar da olabilir. Eğer murabaha sözleşmesi, daha önce taraflar arasında herhangi bir vaatleşme olmaksızın gerçekleştirilmişse normal/klasik murabahadan (Rosman vd., 2016: 4), katılım bankasıyla müşteri arasında vaatleşme sağlanarak gerçekleştirilmişse finansal/çağdaş murabahadan söz edilmiş olur (AAOIFI, 2015: 220; Rosman vd., 2016: 4). Bu ifadeden anlaşılacağı üzere iki tür murabaha vardır. Birincisinde banka müşteriyle herhangi bir vaadleşmede bulunmaksızın mal alır ve bu malı murabaha konusu yapmak üzere aktifinde bekletir. Bu yönteme murabaha denir. Bir diğeri ise banka öncelikle müşteri ile vaadleşir ve müşterinin gösterdiği malı satın alır ve bu malı müşteriye satar. Bu yönteme ise satın alma siparişçisi murabaha denir (Rosman vd., 2016: 4).

Murabaha finansmanı mal alım satımına dayanan İslami finansman araçlarından biridir. Murabaha işlemi İslam dinince meşru görülen ticari işlemler sınıfına girmektedir. Zira Kuran'da Bakara suresinin 275'inci ayetinde belirtildiği üzere, alım satım yani ticaret İslam dininde serbestken faiz şiddetle yasaklanmıştır. Murabaha işlemi ticari bir işlem olarak görüldügü için prensip olarak helal kabul edilmektedir. Ancak, malın özelliklerinin tam olarak belirtilmemesi, malın mülkiyeti tam olarak bankaya geçmeden müşteriye satılması, müşterinin bankayla görüşmeden önce satıcıyla anlaşma sağladıktan sonra bankayla murabaha anlaşması yapması gibi hallerde yapılan işlem meşruiyetini kaybedebilmektedir. Ayrıca konusu altın, gümüş ya da para satışı olan vadeli murabaha işlemi yapılamaz. Diğer taraftan murabaha işleminin daha önce murabaha konusu yapılarak satılmış mal üzerine tekrar yapılması da mümkün değildir (AAOIFI, 2015: 202).

Murabaha işleminde müşteri ihtiyaç duyduğu malı satın almak üzere İslami finans kurumuna (katılım bankası) başvurur. Katılım bankası belirtilen özellikteki malı müşterinin gösterdiği ya da herhangi bir tedarikçiden piyasa fiyatı üzerinden satın alır. Banka satın aldığı bu malı üzerine belirli bir kâr ekleyerek vadeli olarak müşteriye satar. Bu yöntem sayesinde müşteri peşin olarak alacağı malı vadeli olarak satın alma şansı yakalarken, tedarikçi ise peşin satış yapma avantajı sağlamış olur. Banka ise satın alma fiyatının üzerine koymuş olduğu kâr tutarı kadar bir kazanç sağlamış olur. Murabaha işleminin işleyişini daha açık hale getirmek amacıyla aşağıdaki şekil sunulmuştur.

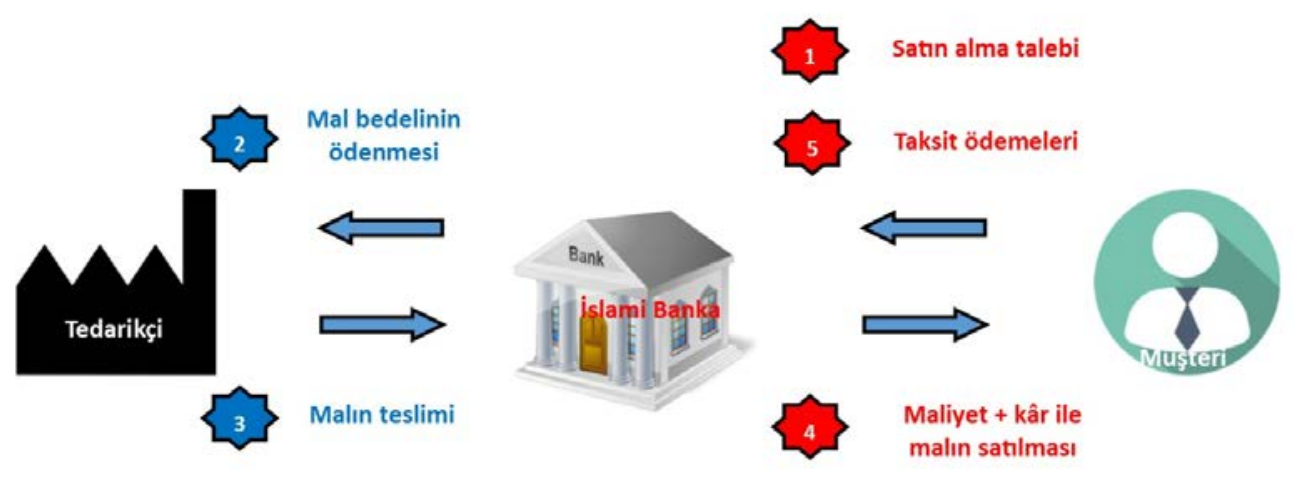

Şekil 1. Murabaha Finansmanının İşleyişi 
Bu gösterimde gerçekleşen adımlar sırasıyla aşağıdaki şekilde ifade edilebilir:

1. Adım: Müşteri (satın alma siparişi veren kişi) katılım bankasına malları satın alması için sipariş verir. Başka bir ifadeyle, müşteri satın alma vaadinde bulunur.

2. Adım: Banka söz konusu malların bedelini tedarikçiye/satıcıya öder.

3. Adım: Banka söz konusu malları teslim alır. Bu teslim mülkiyetin bankaya geçmesinin yanı sıra fiziki olarak ya da teslimi ifade eden diğer şekillerde teslim alınmasını ifade eder.

4. Adım: Banka söz konusu malları satın aldığı fiyatın üzerine kâr ilave ederek müşteriye genellikle taksitli olarak satar ve uygun şekillerde teslim eder.

5. Adım: Müşteri malların bedelini taksitler halinde katılım bankasına öder.

Murabaha işlemi sürecinde katılım bankası murabaha yoluyla satış yapmadan önce malın mülkiyetini almış olması gerekmektedir (AAOIFI, 2015: 206). Katılım bankası murabaha konusu malın tüm sorumluluğunu üstüne alması bakımından, malı müşterisine murabaha yoluyla satmadan önce hakikaten veya hükmen teslim almış olması gerekir. Teslim söz konusu varlığın türüne göre fiziki ya da hukuki teslim olabilir. Bu sayede murabaha konusu malla ilgili ortaya çıkabilecek hasarın hangi aşamaya kadar katılım bankasının, hangi aşamaya kadar kısmının da müşterinin sorumluluğunda olduğu açıklığa kavuşturulmuş olacaktır (AAOIFI, 2015: 208).

Murabaha işleminde birtakım teminat, ücret ve komisyonlar ortaya çıkabilmektedir. Bunların çeşitliliği muhasebeleştirme işlemini de etkileyecektir. Örneğin, katılım bankası murabaha işleminin başında bağlantı/müracaat komisyonu ya da fizibilite çalışması karşılığında bir komisyon alabilir (AAOIFI, 2015: 204). Müşteri katılım bankasından belirli bir satıcıdan malın alınmasını talep ediyorsa, katılım bankası müşteriden söz konusu satıcının yükümlülüklerini tam olarak yerine getireceğine dair kefalet isteyebilir. Bu durumda müşteri, katılım bankasının satıcının yükümlülüklerini yerine getirmesinden kaynaklanan para ve emek kaybı şeklinde doğabilecek zararlarını tazmin etmekle yükümlü olmuş olur. Bir başka durum ise müşterinin bağlayıcı nitelikte taahhütte bulunması durumunda katılım bankası güvence bedeli (kaparo değil) talep edebilir. Daha sonra müşterinin cayması durumunda katılım bankasının zararı bu bedelden tahsil edilebilir. Zararı aşan kısım müşteriye geri iade edilir. Ortaya çıkabilecek fiili zarar malın maliyeti ile bu malı başka bir müşteriye satış bedeli arasındaki farktır. Ancak bu tazminat katılım bankasının mahrum kaldığı kâr ya da kaçırılan firsat maliyetini kapsamaz. Katılım bankasının müşterinin cayması durumu dışında söz konusu güvence bedelini kullanma hakkı yoktur. Bu süreçte ortaya çıkan bir diğer ücret unsuru ise kaparodur. Katılım bankası müşterisine murabaha yoluyla malı satmak üzere sözleşmeyi düzenlerken kaparo alabilir. Müşterinin cayması halinde banka dilerse bu parayı iade etmeyebilir (AAOIFI, 2015, 204-6). Özetlemek gerekirse murabaha işleminde bağlantı/müracaat komisyonu, fizibilite komisyonu, güvence bedeli, teminat, kefalet ve kaparo durumları söz konusu olabilir. 


\section{MURABAHA FINANSMANI YÖNTEMININ TÜRKIYE'DEKİ DURUMU}

Türkiye'de 2005 yılına kadar özel finans kurumu (ÖFK) adıyla faaliyet gösteren katılım bankaları gerçekleştirdikleri murabaha işlemlerinden dolayı 31.07.2004 tarihine kadar Katma Değer Vergisi (KDV) mükellefi olarak hareket etmişlerdir. KDV mükellefi olmalarından dolayı murabaha konusu malın tedarikçiden satın alınıp müşteriye satılması noktasında fatura alma ve düzenleme yükümlülügü taşımıştır. Bu durum o zamanki adıyla özel finans kurumlarının, prosedürlerin çok olması noktasında, geleneksel bankalara göre dezavantajlı olmalarına yol açtığı için 31.07.2004 tarihli ve 25539 sayılı Resmî Gazete'de yayınlanan "5228 Sayılı Bazı Kanunlarda ve 178 Sayılı Kanun Hükmünde Kararnamede Değişiklik Yapılması Hakkında Kanun” ile Vergi Usul Kanununun (VUK) 204'üncü maddesinde 31.07.2004'ten itibaren geçerli olmak üzere yapılan bir düzenlemeyle fatura kesme yükümlülügü kaldırılmıştır. Buna göre VUK'un 204'üncü maddesinde yer alan "Banka, banker ve sigorta şirketleri” ibaresi "Banka (vergi kanunları uygulamasında özel belirleme yapılmadığı sürece, özel finans kurumları banka olarak addolunur), banker ve sigorta şirketleri” şeklinde değiştirilmiştir. Böylelikle özel finans kurumları KDV'den istisna edilerek, Banka ve Sigorta Muameleleri Vergisi (BSMV) mükellefi olmuşlardır. Özel finans kurumları 5411 sayılı Bankacılık Kanunu'nun 1.11.2005 tarihli ve 25983 Mükerrer sayılı Resmi Gazete'de yayınlanarak yürürlüğe girmesiyle birlikte de katılım bankası adını almışlardır. Böylelikle mevduat kabulü hariç geleneksel bankalarca gerçekleştirilen tüm faaliyetleri gerçekleştirme hakkına kavuşmuşlardır.

Şimdiki haliyle katılım bankaları 5411 sayılı Bankacılık Kanunu bakımından sadece fon toplama noktasında ayrılmaktadır. Söz konusu Kanunun 4'üncü maddesine göre katılım bankaları katılım fonu adı altında fon toplama hakkına sahiptir. Bu kapsamda Kanunun 3'üncü maddesinde özel cari hesaplar ve katılma hesapları olmak üzere iki tane katılım fonu tanımlanmıştır. Buna göre özel cari hesaplar katılım bankalarında açılabilen ve istenildiğinde kısmen veya tamamen her an geri çekilebilme özelliği taşıyan ve karşılığında hesap sahibine herhangi bir getiri ödenmeyen fonların oluşturduğu hesaplar şeklinde tanımlanmıştır. Aynı şekilde, katılma hesapları ise katılım bankalarına yatırılan fonların bu kurumlarca kullandırılmasından doğacak kâr veya zarara katılma sonucunu veren, karşılığında hesap sahibine önceden belirlenmiş herhangi bir getiri ödenmeyen ve anaparanın aynen geri ödenmesi garanti edilmeyen fonların oluşturduğu hesaplar şeklinde tanımlanmıştır.

Kanun'da bankacılık faaliyetleri arasında sayılan "nakdi, gayri nakdi her cins ve surette kredi verme işlemleri" katılım bankalarında özelinde dünyadaki yaygın kullanılan isimleriyle murabaha, teverrük, mudaraba, müşareke, istisna ve selem finansmanı şeklinde karşılık bulmaktadır. Maliyet artı kâr satışı şeklinde de ifade edilen murabaha finansmanı yöntemi Türkiye'deki katılım bankaları tarafından en çok kullanılan finansman yöntemidir. Türkiye Katılım Bankaları Birliği (TKBB) verilerine göre 30.6.2020 itibarıyla katılım bankalarınca kullandırılan toplam fon yaklaşık olarak 140 milyar TL düzeyinde olup bunun yaklaşık olarak \%97'si murabaha finansmanıyla kullandırılmıştır.

Türkiye'deki katılım bankaları murabaha finansmanın muhasebeleştirilmesi ve finansal raporlaması noktasında Bankacılık Düzenleme ve Denetleme (BDDK) tarafından 01.11.2006 tarihli ve 26333 sayılı Resmî Gazete'de yayınlanan "Bankaların Muhasebe Uygulamalarına ve Belgelerin Saklanmasına İlişkin Usul ve Esaslar hakkında Yönetmelik” 
hükümleri uyarınca TMS/TFRS'lere uygun olarak hareket etmesi gerekmektedir. Dolayısıyla katılım bankaları murabaha finansmanı kapsamında kullandırmış oldukları fonların muhasebeleştirilmesinde ilgili TMS/TFRS hükümlerine göre yapmaktadırlar.

Diğer taraftan Kamu Gözetim Kurumu (KGK) tarafından yayınlanan Faizsiz Finans Muhasebe Standartları (FFMS) isteğe bağlı olarak katılım bankalarınca uygulanabilmektedir. Buna göre Türkiye'deki katılım bankaları 1 Ocak 2020 tarihinden itibaren, eğer isterlerse murabaha finansmanı kapsamında kullandırmış oldukları fonları, FFMS 28 Murabaha ve Diğer Vadeli Satışlar standardı hükümleri çerçevesinde muhasebeleştirip raporlayabileceklerdir. Ancak bu konuda herhangi bir BDDK düzenlemesi bulunmamakta, sadece bir tavsiye niteliği taşımaktadır. Bununla birlikte uluslararası düzeyde diğer katılım bankalarıyla uyumlu finansal raporlar yayınlanması ve özellikle Ortadoğu ülkelerinden yatırımcıların Türkiye'ye yönelmesini temin etmek amacıyla zorunlu olarak uygulanabileceği öngörülmektedir.

Murabahanın doğru bir şekilde anlaşılması ve uygulanması için AAOIFI tüm faizsiz finans ürünleri için Şer'i Standartlar (Sharia Standards) belirlemiş ve yayınlamıştır. Bu standartlar Türkiye Katılım Bankaları Birliği (TKBB) tarafından 2018 yılında Türkçeleştirilerek Faizsiz Finans Standartları (FFS) adıyla yayınlanmıştır. Bu standartlardan FFS 8 Murabaha standardı satın alma talebinde bulunan müşteriye murabaha yöntemiyle gerçekleştirilecek satışın aşamaları bu işleme başlamak için gereken vaat ve güvence bedeli (hamişülciddiyye) gibi teminatların durumu ile murabaha işleminden doğan alacaklı ve borçlu ilişkisin teminatları ele alınmaktadır. Çalışmada murabaha finansmanının işıleyişi açıklanırken özellikle bu standarttan büyük ölçüde yararlanılmıştır.

\section{MURABAHA FİNANSMANINA İLIŞKIN MUHASEBE VE RAPORLAMA İLKELERI}

Murabaha işlemlerinin muhasebeleştirilmesinde söz konusu olan konular genel olarak aşağıdaki gibidir (Zarfi, 2019: 24):

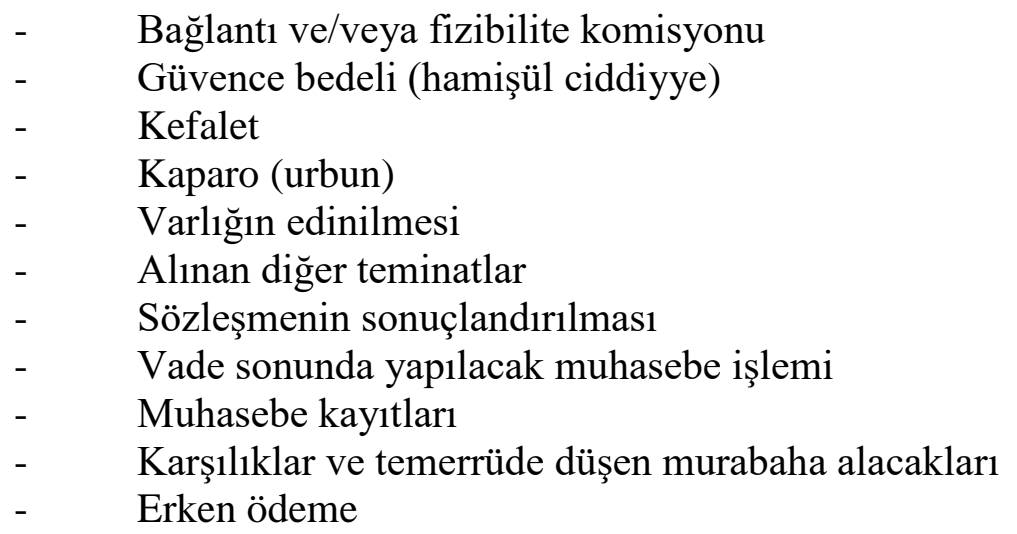

Yukarıda ifade edilen bağlantı komisyonu, fizibilite komisyonu, kefalet ve güvence bedeli katılım bankası ile müşterisi arasında murabaha sözleşmesi kurulmadan önce ortaya çıkar. Kaparo ise sözleşme kurulduktan sonra ödenir. Kaparo sözleşmenin devam etmesi durumunda mal bedelinden düşülür. Müşterinin sözleşmeden cayması durumunda katılım bankasında kalır. 


\subsection{FFMS'ye Göre Muhasebe ve Raporlaması İlkeleri}

FFMS 28 Murabaha ve Diğer Vadeli Satışlar Standardı alıcı ve satıcı tarafindan Murabaha ve diğer vadeli satış işlemlerinde uygulanacak finansal tablolara alma (tanımlama), ölçüm ve açıklamalara ilişkin uygun muhasebe ve raporlama esaslarını belirlemek amacıyla düzenlenmiştir.

\section{Satıcı Açısından}

Standartta olağan iş akışı içinde satılmak üzere üretilmekte olan veya elde tutulan varlık anlamında kullanılan stoklar, katılım bankası ilgili stok üzerinde kontrole sahip olduğunda (mülkiyetten kaynaklanan risk ve getirileri önemli ölçüde edindiğinde) finansal tablolara alınabilir. Stoklar başlangıçta maliyet değeri üzerinden finansal tablolara yansitılır. Stok maliyeti tüm satın alma maliyetleri ile stokun mevcut konumuna ve durumuna getirilmesi sırasında ortaya çıkan diğer maliyetleri kapsar. Ticari iskontolar, indirimler ve diğer benzer kalemler maliyetlerden indirilir. Bu maliyetler aşağıda belirtilen kalemlerden oluşur:

- $\quad$ Her türlü vergi (sonradan iade alınabilecekler hariç)

- $\quad$ İlgili Tekâfül maliyetleri dâhil nakliye ve elleçleme (handling) maliyetleri

- $\quad$ Müsşerinin vekil sıfatıyla katlandığı maliyetler ile vekile ödenen her türlü ücret dahil varlığın mevcut konumuna ve durumuna getirilmesiyle doğrudan ilişkilendirilebilen diğer tüm maliyetler

Stoklar mevcut konum ve duruma getirildikten sonra ortaya çıkan giderler doğrudan ilgili dönem gider olarak yazılır. Stoklar sonraki ölçümleri ise maliyet değeri ile net gerçekleşebilir değerinden düşük olanı üzerinden yapılır. Standarda göre net gerçekleşebilir değer (NGD) faizsiz finans kuruluşuna özgü faktörler dikkate alınmak suretiyle; olağan iş akışı içinde tahmini satış fiyatından, tahmini tamamlanma maliyetlerinin ve satışı gerçekleştirmek için gerekli olan tahmini maliyetlerin düşülmesiyle elde edilen tutarı ifade etmektedir. Ancak kredibilitesi yeterli bir müşterinin söz konusu stokları maliyet değeri ya da bu değerin üzerinde bir fiyattan satın alması yönünde bağlayıcı bir vaadi varsa, katılım bankası varlığın gerçeğe uygun değerindeki dalgalanmayı dikkate almaksızın varlığı maliyet değeri üzerinden ölçmeye devam eder. Söz konusu standartta gerçeğe uygun değer piyasa katılımcıları arasında, ölçüm tarihinde olağan bir işlemde bir varlığın satışından elde edilecek veya bir yükümlülüğün devrinde ödenecek fiyat şeklinde tanımlanmıştır. Ancak böyle bir bağlayıcı durum söz konusu değilse, maliyet değerinin net gerçekleşebilir değerin altına inmesi durumunda stokların defter değeri net gerçekleşebilir değere indirgenecek şekilde düzeltilir. Stokların finansal tablo dışı bırakılması ilke olarak söz konusu varlıktan faizsiz finans kuruluşuna gelecekte ekonomik fayda akışının beklenmemesi durumunun ortaya çıkması halinde gerçekleşir. Katılım bankası bu durumu göz önünde bulundurarak aşağıdaki durumlardan birinin ortaya çıkması halinde stoku bilanço dışı bırakır:

a) Kuruluşun, satış yoluyla kontrolü alıcıya devretmesi

b) Kuruluşun, kaybolma ya da çalınma gibi bir nedenle, stok üzerindeki kontrolü kaybetmesi ya da

c) Stokların, teknolojik eskime, yasal kısıtlamalar ya da alıcısının olmaması gibi bir nedenle, gelecekte ekonomik fayda sağlama kapasitesini yitirmesi 
Murabaha işleminden katılım bankası lehine doğan alacaklar ve hasılat murabaha ya da vadeli satış sözleşmesi kapsamında söz konusu stok satıldığında finansal tablolara alınır. Murabaha alacakları itibari değeri (brüt tutar ya da fatura tutarı) üzerinden finansal tablolara alınır. Brüt alacakların sonraki ölçümleri ödenmemiş tutarlardan, varsa kredi zarar karşılıkları düşüldükten sonra kalan tutar üzerinden izlenir. Ödenmemiş tutar, alacakların brüt tutarından tahsilatlar ve varsa izin verilen iskonto ve indirimler dâhil diğer düzeltmeler düşüldükten sonra kalan tutardır. Kredi zararları karşılığının muhasebeleştirilmesinde ise FFMS 30 Değer Düşüklüğü, Kredi Zararları ve Ekonomik Açıdan Dezavantajı Taahhütler standardına göre hareket edilir. Murabaha alacaklarının finansal tablo dışı bırakılması ilke olarak söz konusu alacaklardan faizsiz finans kuruluşuna gelecekte ekonomik fayda akışının beklenmemesi durumunun ortaya çıkması halinde gerçekleşir. Katılım bankası bu durumu göz önünde bulundurarak aşağıdaki durumlardan birinin ortaya çıkması halinde stoku bilanço dışı bırakır:

a) Müşterinin kalan tüm borcunu ödemesi,

b) Alacağın defter değerinin, müşterinin acze düşmesi nedeniyle tahsil edilemeyecek olması ya da

c) Kuruluşun, alacağını kayıttan düşmek ya da müşteriye hibe etmek suretiyle hakkından vazgeçmeye karar vermiş olması

Stoklar murabaha ya da vadeli satış sözleşmesi kapsamında satıldığında, satıcı tarafindan ilk defa alacakları ve hasılatı finansal tablolarına alınırken, bu stokların defter değeri, katlanılan tüm doğrudan giderlerle birlikte, ilgili hasılatın finansal tablolara alındığ dönemde satışların maliyeti olarak finansal tablolara alınır.

Vadeli murabahada ya da diğer vadeli satışta finansal tablolara alınan hasılat ile satışların maliyeti arasındaki fark ertelenmiş kâr olarak ifade edilir. Ertelenmiş kâr ilgili alacakları düzenleyici bir varlık hesabı olarak bir ertelenmiş kâr hesabında izlenir. Ancak, peşin murabahada ya da diğer peşin satışta, ortaya çıkan kâr ertelenmez. Orijinal vadesi 12 aydan uzun olan; taksitler hâlinde ya da vade sonunda defaten ödeme yapılacak işlemlerde, kârın zamana orantılı olarak itfa edilmesinde başvurulacak uygun yöntem, işlemdeki zımni kârı esas alan etkin kâr yöntemidir. Orijinal vadesi 12 ay ya da daha kısa olan, vade sonunda defaten ödeme yapılacak işlemlerde, kârın sözleşmedeki kredi dönemi boyunca doğrusal olarak dağıtımına izin verilir. Temerrüt ya da olası temerrüt durumlarında, ertelenmiş kâra ilgili FFMS 30 Değer Düşüklüğü, Kredi Zararları ve Ekonomik Açıdan Dezavantajlı Taahhütler standardı hükümleri uygulanır. 
Tablo 1. Satıcı Açısından Murabaha Stokları ve Alacaklarının Raporlanması

\begin{tabular}{|c|c|c|c|c|}
\hline & $\begin{array}{c}\text { İlk Defa Finansal } \\
\text { Tablolara Alma }\end{array}$ & İlk Ölçme & Sonraki Ölçme & Finansal Tablo Dışı Bırakma \\
\hline Stoklar & $\begin{array}{l}\text { Kontrol elde } \\
\text { edildiğinde }\end{array}$ & $\begin{array}{l}\text { Maliyet değeri } \\
\text { üzerinden }\end{array}$ & $\begin{array}{l}\text { Maliyet değeri } \\
\text { ile net } \\
\text { gerçekleşebilir } \\
\text { değerinden } \\
\text { düşük olanı }\end{array}$ & $\begin{array}{l}\text { Gelecekte ekonomik fayda akışının } \\
\text { beklenmemesi dikkate alınarak; } \\
\text { a) Kontrol alıcıya devredildiğinde } \\
\text { b) Kontrol kaybedildiğinde } \\
\text { c) Gelecekteki ekonomik fayda } \\
\text { yitirildiğinde }\end{array}$ \\
\hline Alacaklar & $\begin{array}{l}\text { Satış işlemi } \\
\text { gerçekleştiğinde } \\
\text { (kontrol } \\
\text { devredildiğinde) }\end{array}$ & $\begin{array}{l}\text { İtibari değeri } \\
\text { (brüt tutar ya } \\
\text { da fatura } \\
\text { tutarı) } \\
\text { üzerinden }\end{array}$ & $\begin{array}{l}\text { Ödenmemiş } \\
\text { tutarlardan, } \\
\text { varsa kredi zarar } \\
\text { karşılıkları } \\
\text { düşüldükten } \\
\text { sonraki kalan } \\
\text { tutar üzerinden }\end{array}$ & $\begin{array}{l}\text { Gelecekte ekonomik fayda akışının } \\
\text { beklenmemesi dikkate alınarak; } \\
\text { a) Müşterinin kalan tüm borcunu } \\
\text { ödemesi } \\
\text { b) Alacağın değersiz hale gelmesi } \\
\text { c) Alacaktan vazgeçme, bağışlama }\end{array}$ \\
\hline
\end{tabular}

Tablo 2. Satıcı Açısından Murabahayla İlgili Diğer Hususların Raporlanması

\begin{tabular}{|c|c|}
\hline İŞLEM VEYA OLAY & MUHASEBE UYGULAMASI \\
\hline Hasılat & Satış işlemi gerçekleştiğinde (kontrol devredildiğinde) \\
\hline Satışların Maliyeti & $\begin{array}{l}\text { Hasılatın finansal tablolara alındığı dönemde, katlanılan tüm } \\
\text { doğrudan giderlerle birlikte varlığın defter değeri üzerinden }\end{array}$ \\
\hline Kâr & $\begin{array}{l}\text { Peşin satışta satış gerçekleştiği anda, vadeli satışta ise kredi dönemi } \\
\text { boyunca }\end{array}$ \\
\hline Ertelenmiş Kâr & Sözleşmedeki kredi dönemi boyunca itfa edilerek gelirlere aktarılır. \\
\hline $\begin{array}{l}\text { Alacaktan Vazgeçme, İskonto ve } \\
\text { Kayıttan Düşme }\end{array}$ & $\begin{array}{l}\text { 1) Silinen/vazgeçilen tutar, ilgili işlemde ortaya çıkan ertelenmiş } \\
\text { kârın varsa mevcut bakiyesinden indirilir, } \\
\text { 2) Varsa kalan tutar, cari raporlama döneminde itfa edilen } \\
\text { ertelenmiş kârdan/finansal tablolara alınan kârdan indirilir } \\
\text { 3) Varsa kalan tutar, dönemin gideri olarak gelir tablosuna alınır. }\end{array}$ \\
\hline $\begin{array}{l}\text { Murabaha sözleşmesinin müzakere } \\
\text { edilmesi ve düzenlenmesiyle ilgili } \\
\text { işlem maliyetleri }\end{array}$ & $\begin{array}{l}\text { Müşteri tarafından karşılanan kısmı düşüldükten sonra, katlanıldıkları } \\
\text { dönemin gelir tablosuna alınır. }\end{array}$ \\
\hline $\begin{array}{l}\text { Yapılandırma ve diğer hizmet } \\
\text { ücretleri }\end{array}$ & $\begin{array}{l}\text { Müşteriye yansıtılan yapılandırma ücretleri ya da benzer ücretler, } \\
\text { ilgili hizmetler sağlandığında finansal tablolara alınır. }\end{array}$ \\
\hline $\begin{array}{l}\text { Stoklar için sonradan yapılan } \\
\text { iskontolar }\end{array}$ & $\begin{array}{l}\text { 1. Satışların maliyetinden indirilir. } \\
\text { 2. Müşteriye yansıtılması durumunda brüt hasılat tutarından indirilir. } \\
\text { 3. İskonto müşteriye yansıtılmayacaksa; peşin murabahada ilgili } \\
\text { dönemin gelir tablosuna alınır, vadeli murabahada ise ertelenmiş } \\
\text { kâr arttırılır ve buna göre itfa edilir. }\end{array}$ \\
\hline Güvence bedeli ve kaparo & Başlangıçta her ikisi de yükümlülük olarak finansal tablolara alınır. \\
\hline
\end{tabular}




\begin{tabular}{|l|l|}
\hline & $\begin{array}{l}\text { Murabaha işlemi tekemmül ettiğinde güvence bedeli yükümlülük } \\
\text { olarak sunulmaya devam eder, kaparo ise alacaklardan indirilir. }\end{array}$ \\
\hline $\begin{array}{l}\text { Temerrüt ve gecikmeli ödemeler } \\
\text { karşılığında müşteri tarafından } \\
\text { verilen sadakalar }\end{array}$ & $\begin{array}{l}\text { Satıcının geliri olarak finansal tablolara alınmaz ve alındığında } \\
\text { doğrudan ödenecek sadakalarda izlenir. }\end{array}$ \\
\hline
\end{tabular}

\section{Alıcı Açısından}

Murabaha ve vadeli satışlarla edinilen varlıklar sözleşme tekemmül ettiğinde (sözleşme tüm taraflar açısından yasal olarak bağlayıcı olduğunda) ve alıcı varlığın kontrolünü elde ettiğinde satın alınmış kabul edilir. Edinilen varlık, başlangıçta maliyeti değeri üzerinden finansal tablolara alınır. Burada maliyet varlığın itibari değeri ile alımla ilgili olarak katlanılan doğrudan maliyetlerin toplamını, itibari değer ise satıcının işlemden elde ettiği kâr dâhil brüt fatura tutarını ifade etmektedir. Bu tür varlıklar, alıcının defterlerinde ilgili FFMS'ye göre raporlanır ve sınıflandırılır. Sözleşmeye konu varlıkla ilgili belirli bir FFMS'nin yoksa, bu FFMS 28'e bağlı kalınarak genel kabul görmüş muhasebe ilkeleri uygulanır (FFMS 28: paraf. 40-41). Varlığın sonraki ölçümleri ise FFMS 28'e bağlı kalınarak, ilgili FFMS uyarınca uygun varlık sınıfı için geçerli olan muhasebe ilkelerine ya da genel kabul görmüş muhasebe ilkelerine göre yapılır. Her bir raporlama dönemi sonunda, stok niteliğindeki varlıklar için net gerçekleşebilir değere göre düzeltme yapılıp yapılmayacağı test edilir ve diğer varlıklar ilgili FFMS ya da GKGMİ doğrultusunda değer düşüklügü testine tabi tutulur (FFMS 28: paraf. 43-44). Murabaha ve vadeli satışlardan doğan yükümlülükler alıcı tarafından, ilgili varlığın kontrolü elde edildiğinde, itibari değerine eşit bir tutar üzerinden finansal tablolara alınır. Sonraki ölçümleri ise ödenmemiş tutarları üzerinden izlenir. Borçların ödenmemiş tutarları, yükümlülüklerin brüt tutarından geri ödemeler ve varsa satıcı tarafından yapılan iskonto ve diğer indirimler dâhil düzeltmeler düşüldükten sonra kalan tutarı ifade eder (FFMS 28: paraf. 42, 45 ve 46). Murabaha ve vadeli satışlar sonucunda edinilen varlıklar ve üstlenilen yükümlülüklerin bu açıklamalardan yola çıkarak muhasebeleştirilme ve raporlanma ilkeleri aşağıdaki tabloda özetlenmeye çalışılmıştır.

Tablo 3. Alıcı Açısından Murabaha Varlıkları ve Borçlarının Raporlanması

\begin{tabular}{|c|c|c|c|}
\hline & $\begin{array}{l}\text { İlk Defa Finansal } \\
\text { Tablolara Alma }\end{array}$ & İlk Ölçme & Sonraki Ölçme \\
\hline Varlıklar & $\begin{array}{l}\text { Varlığın kontrolü elde } \\
\text { edildiğinde }\end{array}$ & Maliyet değeri üzerinden & $\begin{array}{l}\text { Stoklar net gerçekleşebilir } \\
\text { değerle, diğer varlıklar ilgili } \\
\text { FFMS ya da GKGMI }\end{array}$ \\
\hline Yükümlülükler & $\begin{array}{l}\text { Varlığın kontrolü elde } \\
\text { edildiğinde }\end{array}$ & $\begin{array}{l}\text { İtibari değerine eşit bir tutar } \\
\text { üzerinden }\end{array}$ & $\begin{array}{l}\text { Ödenmemiş tutarları } \\
\text { üzerinden izlenir }\end{array}$ \\
\hline
\end{tabular}

Satıcı tarafından toplam borcun silinen/vazgeçilen kısmı ilk olarak, ilgili varlığın değerinden bir indirim olarak finansal tablolara alınır. İkinci olarak da varlığın satılması ya da başka bir yolla elden çıkarılması durumunda, söz konusu tutar, tahsilinden vazgeçildiği dönemde gelir olarak finansal tablolara alınır (FFMS 28: paraf. 47). Alıcı tarafından sözleşme şartlarına bağlı olarak başlangıçta güvence bedeli ve kaparo adı altında satıcıya ödenen teminat veya avans, alıcının finansal tablolarında teminat ya da alımlar için ödenen avans olarak sunulur. Murabaha ya da vadeli satış işlemi tekemmül ettiğinde teminat niteliğindeki güvence bedeli, finansal tablolarda teminat olarak sunulmaya devam edilir ve satıciyla 
sözleşmeye bağlı olarak mutabık kalınmadığı sürece murabaha ve vadeli satı̧̧lardan doğan borçlarla netleştirilmez. Avans ödemesi niteliğindeki kaparo ise murabaha ve vadeli satışlardan doğan borçlardan indirilir (FFMS 28: paraf. 48-49). Vazgeçme, iskonto ve kayıtttan düşme, güvence bedeli ve kaparo ile ilgili muhasebeleştirilme ve raporlanma ilkeleri aşağıdaki tabloda özetlenmeye çalışılmıştır.

Tablo 4. Alıcı Açısından Murabahayla İlgili Diğer Hususların Raporlanması

\begin{tabular}{|l|l|}
\hline İşlem veya Olay & Muhasebe Uygulaması \\
\hline $\begin{array}{l}\text { Vazgeçme, İskonto ve Kayıttan } \\
\text { Düşme }\end{array}$ & $\begin{array}{l}\text { Satıcı tarafından toplam borcun silinen/vazgeçilen kısmı varlık } \\
\text { mevcutsa değerinden bir indirim olarak, mevcut değilse (satılışs ya } \\
\text { da bir şekilde elden çıkarılmışsa) gelir olarak finansal tablolara alınır. }\end{array}$ \\
\hline Güvence bedeli ve kaparo & $\begin{array}{l}\text { Teminat ya da ödenen avans olarak sunulur. Murabaha ya da vadeli } \\
\text { satıs işlemi tekemmül ettiğinde teminat niteliğindeki güvence bedeli } \\
\text { teminat olarak sunulmaya devam eder ve avans ödemesi niteliğindeki } \\
\text { kaparo ise ilgili borçlardan indirilir. }\end{array}$ \\
\hline
\end{tabular}

\subsection{TMS//TFRS'ye Göre Muhasebe ve Raporlaması İlkeleri}

Murabaha finansmanı alacakları TFRS 9'un finansal varlık tanımının yapıldığı 11.c.i. maddesi uyarınca "başka bir işletmeden nakit ya da başka bir finansal varlık almak için düzenlenen sözleşmeden doğan hak" olması bakımından bir finansal varlık olarak değerlendirilebilir. TFRS 9, m. 3.1.1 uyarınca işletme (katılım bankası), finansal bir varlığı veya finansal bir yükümlülüğü, sadece finansal araca ilişkin sözleşme hükümlerine taraf olduğunda finansal durum tablosuna alır. Dolayısıyla katılım bankası müşteriyle kendisi arasında bireysel ya da kurumsal finansman desteği adı altında düzenlenen murabaha finansmanı sözleşmesinde fon kullandıran taraf olarak yer almasından dolayı, murabaha finansmanından doğan alacakları ilk defa finansal tablolara alma ön koşulunu sağlamış olur.

Banka bir finansal varlığı ilk defa finansal tablolara alırken sınıflandırma için 4.1.14.1.5 paragraflarına göre, ölçüm için ise 5.1.1-5.1.3 paragraflarına göre hareket eder. Buna göre, banka finansal varlıklarını (a) finansal varlıkların yönetimi için kullandığı iş modeli ya da (b) finansal varlığın sözleşmeye bağlı nakit akışlarının özelliklerini esas alarak aşağıda belirtilenlerden biri olarak sinıflandırır:

a) İtfa edilmiş maliyeti üzerinden ölçülen

b) Gerçeğe uygun değer değişimi diğer kapsamlı gelire yansitılarak ölçülen

c) Gerçeğe uygun değer değişimi kâr veya zarara yansıtılarak ölçülen

Murabaha finansmanı alacakları, katılım bankasının TFRS 9'un 4.1.2 maddesinde belirtilen her iki şartı karşılaması bakımdan finansal tablolarda "itfa edilmiş maliyeti üzerinden ölçülen" olarak sınıflandırılabilir:

(a) Finansal varlığın, sözleşmeye bağlı nakit akışlarının tahsil edilmesini amaçlayan bir iş modeli kapsamında elde tutulması,

(b) Finansal varlığa ilişkin sözleşme şartlarının, belirli tarihlerde sadece anapara ve anapara bakiyesinden kaynaklanan faiz ödemelerini içeren nakit akışlarına yol açması. 
Banka “itfa edilmiş maliyeti üzerinden ölçülen” olarak sınıflandırdığı murabaha alacaklarını TFRS 9'un 5.1.1 maddesi uyarınca gerçeğe uygun değerinden ölçer. Bu türden bir varlığın gerçeğe uygun değeri belirlenirken işlem maliyetleri de dikkate alınır. TFRS 9'un 5.2.1 maddesi uyarınca da itfa edilmiş maliyeti üzerinden ölçülen olarak sınıflandığı murabaha alacaklarını "itfa edilmiş maliyeti” üzerinden ölçer.

Tablo 5. TFRS 9: Finansal Araçlar Standardına Göre Murabaha Finansmanı

Alacaklarının Muhasebeleştirilmesi

\begin{tabular}{|l|l|}
\hline $\begin{array}{l}\text { İlk defa finansal } \\
\text { tablolara alma }\end{array}$ & Finansal araca ilişkin sözleşme hükümlerine taraf olunduğunda \\
\hline İlk ölçme & Gerçeğe uygun değer üzerinden \\
\hline İlk sınıflandırma & İtfa edilmiş maliyet üzerinden ölçülen olarak \\
\hline Sonraki ölçme & İtfa edilmiş maliyet üzerinden \\
\hline $\begin{array}{l}\text { Finansal tablo dışı } \\
\text { bırakma }\end{array}$ & $\begin{array}{l}\text { Finansal varlıktan kaynaklanan nakit akışlarına ilişkin sözleşmeden doğan hakların } \\
\text { süresinin dolması ya da finansal varlığı devredilmesi }\end{array}$ \\
\hline
\end{tabular}

TFRS 9'un 5.4.1 maddesi uyarınca, itfa edilmiş maliyeti üzerinden ölçülen finansal varlıklardan elde edilen faiz geliri etkin faiz yöntemi kullanılarak hesaplanır. Bu gelir söz konusu finansal varlığın brüt defter değerine etkin faiz oranı uygulanmak suretiyle hesaplanır. Etkin faiz oranı TFRS 9'un EK-A kısmında tanımlandığı üzere finansal varlığın veya yükümlülüğün beklenen ömrü boyunca gerçekleşmesi tahmin edilen gelecekteki nakit ödeme veya tahsilatları, finansal varlığın brüt defter değerine veya finansal yükümlülügüü itfa edilmiş maliyetine indirgeyen orandır.

Uygulamada murabaha finansmanından doğan alacaklar katılım bankasının finansal durum tablosunda "Kredi ve Alacaklar" gösterilmektedir. Banka, krediler ve alacakların ilk kaydını gerçeğe uygun değerini yansıttığı öngörülen elde etme maliyetiyle yapmakta, kayda alınmayı izleyen dönemlerde iç verim yöntemi kullanılarak iskonto edilmiş değerleri üzerinden muhasebeleştirilmekte ve bunların teminatı olarak alınan varlıklarla ilgili olarak ödenen harç, işlem gideri ve bunun gibi diğer masrafları işlem maliyetinin bir bölümü olarak kabul etmeyip doğrudan gider hesaplarına yansıtmaktadır (Kuveyt Türk 2017 Faaliyet Raporu, s.125).

TMS/TFRS açısından murabaha finansmanı işlemine konu olan malların stok olarak değerlendirilmesi konusunda "TMS 2 Stoklar" standard1 ve "Finansal Raporlamaya İlişkin Kavramsal Çerçeve" hükümleri incelenmiştir. TMS 2 Stoklar standardına göre stoklar aşağıdaki şekillerde olabilen varlıklardır:

(a) Olağan iş akışı içinde satılmak üzere elde tutulan

(b) Olağan iş akışı içinde satılmak üzere üretilmekte olan veya

(c) Üretim sürecinde veya hizmet sunumunda kullanılacak hammadde ve malzeme şeklinde bulunan

Finansal Raporlamaya İlişkin Kavramsal Çerçeveye varlık geçmişteki olayların bir sonucu olarak işletme tarafından kontrol edilen mevcut bir ekonomik kaynaktır. Bu tanımdan hareketle işlem veya olayın varlık olabilmesi için ekonomik fayda üretme potansiyeline ve kontrol edilme özelliğine sahip olması gerekir. Günümüz murabaha finansmanı işlemlerinde katılım bankasının rolü sadece müşteriye finanse etmekle sınırlıdır. Murabaha süreci içerisinde murabaha konusu mal hiçbir şekilde katılım bankasının kontrolüne geçmemekte, 
doğrudan doğruya satıcı (tedarikçi) firmadan müşteriye transfer edilmektedir. Söz konu malla ilgili sonradan yaşanabilecek her türlü sorundan banka değil satıcı sorumlu olmaktadır. Dolayısıyla katılım bankasının murabaha konusu varlığı, stok adıyla bir varlık unsuru olarak finansal durum tablosuna almasını gerektirecek herhangi bir durum söz konusu olmamaktadır.

\section{6. ÖRNEK UYGULAMA}

Said Bey peşin fiyatı 250.000 TL olan bir otomobili satın almak üzere bir katılım bankasına başvurmuştur. Otomobil 01.10.2020 tarihinde banka tarafindan 250.000 TL'ye satın alınarak yine aynı tarihte söz konusu müşteriye \%1,23 aylık kâr oranı üzerinde 24 ay vadeli olarak aşağıdaki koşullarda satılmıştır.

Ödeme Planı

\begin{tabular}{|c|c|c|c|c|c|c|c|}
\hline $\begin{array}{c}\text { Taksit } \\
\text { No }\end{array}$ & Ödeme Tarihi & $\begin{array}{l}\text { Taksit } \\
\text { Tutarı }\end{array}$ & Ana Para & $\begin{array}{c}\text { Kalan Ana } \\
\text { Para }\end{array}$ & Kâr Tutarı & KKDF & BSMV \\
\hline 1 & 31.10 .2020 & $12.446,26$ & $8.756,26$ & $241.243,74$ & $3.075,00$ & 461,25 & 153,75 \\
\hline 2 & 30.11 .2020 & $12.446,26$ & $8.885,50$ & $232.358,24$ & $2.967,30$ & 445,1 & 148,36 \\
\hline 3 & 31.12 .2020 & $12.446,26$ & $9.016,65$ & $223.341,59$ & $2.858,01$ & 428,7 & 142,9 \\
\hline 4 & 31.01 .2021 & $12.446,26$ & $9.149,74$ & $214.191,85$ & $2.747,10$ & 412,06 & 137,36 \\
\hline 5 & 28.02 .2021 & $12.446,26$ & $9.284,79$ & $204.907,06$ & $2.634,56$ & 395,18 & 131,73 \\
\hline 6 & 31.03 .2021 & $12.446,26$ & $9.421,83$ & $195.485,23$ & $2.520,36$ & 378,05 & 126,02 \\
\hline 7 & 30.04 .2021 & $12.446,26$ & $9.560,90$ & $185.924,33$ & $2.404,47$ & 360,67 & 120,22 \\
\hline 8 & 31.05 .2021 & $12.446,26$ & $9.702,02$ & $176.222,31$ & $2.286,87$ & 343,03 & 114,34 \\
\hline 9 & 30.06 .2021 & $12.446,26$ & $9.845,22$ & $166.377,09$ & $2.167,53$ & 325,13 & 108,38 \\
\hline 10 & 31.07 .2021 & $12.446,26$ & $9.990,53$ & $156.386,56$ & $2.046,44$ & 306,97 & 102,32 \\
\hline 11 & 31.08 .2021 & $12.446,26$ & $10.138,00$ & $146.248,56$ & $1.923,55$ & 288,53 & 96,18 \\
\hline 12 & 30.09 .2021 & $12.446,26$ & $10.287,63$ & $135.960,93$ & $1.798,86$ & 269,83 & 89,94 \\
\hline 13 & 31.10 .2021 & $12.446,26$ & $10.439,47$ & $125.521,46$ & $1.672,32$ & 250,85 & 83,62 \\
\hline 14 & 30.11 .2021 & $12.446,26$ & $10.593,56$ & $114.927,90$ & $1.543,91$ & 231,59 & 77,2 \\
\hline 15 & 31.12.2021 & $12.446,26$ & $10.749,93$ & $104.177,97$ & $1.413,61$ & 212,04 & 70,68 \\
\hline 16 & 31.01 .2022 & $12.446,26$ & $10.908,59$ & $93.269,38$ & $1.281,39$ & 192,21 & 64,07 \\
\hline 17 & 28.02 .2022 & $12.446,26$ & $11.069,61$ & $82.199,77$ & $1.147,21$ & 172,08 & 57,36 \\
\hline 18 & 31.03 .2022 & $12.446,26$ & $11.232,99$ & $70.966,78$ & $1.011,06$ & 151,66 & 50,55 \\
\hline 19 & 30.04 .2022 & $12.446,26$ & $11.398,80$ & $59.567,98$ & 872,89 & 130,93 & 43,64 \\
\hline 20 & 31.05 .2022 & $12.446,26$ & $11.567,04$ & $48.000,94$ & 732,69 & 109,9 & 36,63 \\
\hline 21 & 30.06 .2022 & $12.446,26$ & $11.737,77$ & $36.263,17$ & 590,41 & 88,56 & 29,52 \\
\hline 22 & 31.07 .2022 & $12.446,26$ & $11.911,01$ & $24.352,16$ & 446,04 & 66,91 & 22,3 \\
\hline 23 & 31.08 .2022 & $12.446,26$ & $12.086,82$ & $12.265,34$ & 299,53 & 44,93 & 14,98 \\
\hline 24 & 30.09 .2022 & $12.446,37$ & $12.265,34$ & 0 & 150,86 & 22,63 & 7,54 \\
\hline \multicolumn{2}{|c|}{ Toplam } & 298.710,35 & $250.000,00$ & & $40.591,97$ & $6.088,79$ & $2.029,59$ \\
\hline
\end{tabular}

Yukarıdaki ödeme tablosuna göre firma her ayın sonunda 12.446,26 TL aylık taksitler halinde bankaya geri ödeme yapacaktır. Örneğe ilişkin yevmiye kayıtları öncelikle TMS/TFRS'ye, ardından FFMS'ye göre yapılacaktır. 


\subsection{TMS/TFRS’ye göre Murabaha Finansmanının Muhasebeleştirilmesi}

TMS/TFRS'ye göre murabaha finansmanı işleminin muhasebe kayıtları yapılırken Bankacılık Düzenleme ve Denetleme Kurumu (BDDK) tarafindan 26.01.2007 tarihli ve 26415 Mükerrer sayılı Resmî Gazete'de yayınlanan "Katılım Bankalarınca Uygulanacak Tekdüzen Hesap Planı ve İzahnamesi Hakkında Tebliğ" esas alınmıştır. Söz konusu hesap planında örneğin çözümünde kullanılacak hesaplar aşağıdaki gibidir.

\section{VARLIK HESAPLARI}

118 KISA VADELİ DİĞER KREDİLER - T.P.

118.20. Tüketici Kredileri

118.20.1. Taşıt Kredileri

118.20.1.0. Özkaynaklardan

220 KREDİ KÂR PAYI GELİR TAHAKKUK REESKONTLARI - T.P.

220.00. Kâr Payı Tahakkukları

220.00.0. Özkaynaklardan

\section{KAYNAK HESAPLARI}

380 ÖDENECEK VERGİ, RESIM, HARÇ VE PRIMLER - T.P.

380.00. Ödenecek Vergiler

380.00.5 BSMV

390 MUHTELIF BORÇLAR - T.P.

390.22. KKDF'ye Devredilecek Kesintiler

\section{GELIR TABLOSU HESAPLARI}

518 KISA VADELİ DİĞER KREDILLERDEN ALINAN KÂR PAYLARI - T.P.

518.20. Tüketici Kredilerinden

518.20.0 Özkaynaklardan

"220 Kredi Kâr Payı Gelir Tahakkuk Reeskontları - Türk Parası" defterikebir hesabının altında bulunan "220.00. Kâr Payı Tahakkukları" yardımcı hesabı kredilerin dönem kârını ilgilendirdiği halde henüz tahsil olunmamış kâr paylarının izlenmesinde kullanılmaktadır. Kâr payları tahakkuk yöntemiyle "518 Kısa Vadeli Diğer Kredilerden Alınan Kâr Payları" defterikebir hesabına alacak yazılmak üzere "220.00. Kâr Payı Tahakkukları" yardımcı hesabına borç kaydedilir. Aynı şekilde 220 nolu hesabın altında bulunan "220.01. Kâr Payı Reeskontları" yardımc1 hesabı ise dönem sonları itibarıyla tahakkuk dönemi gelmemiş tüm krediler için, o dönemi ilgilendiren kâr paylarının reeskontlarının izlenmesinde kullanılmaktadır. Kredilere ilişkin reeskontlar "220.01. Kâr Payı Reeskontları" yardımcı hesabına borç, "518 Kısa Vadeli Diğer Kredilerden Alınan Kâr Payları" defteri kebir hesabına ise alacak kaydı yapılır. Örnekte, dikkat edilecek olursa ödeme tarihleri aynı zamanda ilgili ayın son günüdür. Dolayısıyla her ayın sonu itibarıyla kâr payları tahakkuk etmiş olmakta ve o gün itibarıyla tahsil edilebilir duruma gelmektedir. Bu bakımdan yevmiye kayıtlarında "220 Kredi Kâr Payı Gelir Tahakkuk Reeskontları" defterikebir hesabının "220.00. Kâr Payı Tahakkukları” alt hesabı kullanılmıştır. 
Murabaha işlemi TMS/TFRS'ye göre normal bir kredi işlemi gibi muhasebeleştirilmektedir. Bunun en temel sebebi şu anki katılım bankalarının mevcut haliyle kullandırmış oldukları finansmanların satış işlemi şartını sağlamadığıdır. Çünkü TMS/TFRS'ye göre bir işlemin satı̧̧ işlemi sayılabilmesi için varlığın kontrolünün risk ve faydalarıyla birlikte karşı tarafa geçmesi gerekmektedir. Katılım bankası mevcut finansman kullandırma uygulamalarında varlığın kontrolünü üzerine almamakta, doğrudan satıcıdan müşterisine transfer edilmesine aracılık etmektedir. Bu bakımdan TMS/TFRS'ye göre murabaha adı altında yapılan fon kullandırma işlemi, her ne kadar satış işlemi adı altında yürütülse de özün öncelliği kavramı bakımından mevcut haliyle bir kredi kullandırma işlemidir. $\mathrm{Bu}$ açıklamalar doğrultusunda banka tarafindan yapılacak yevmiye kayıtları aşağıdaki gibi olacaktır. İlk olarak banka müşteri adına satıcıya ödeme yaptığında aşağıdaki gibi bir kayıt yapacaktır.

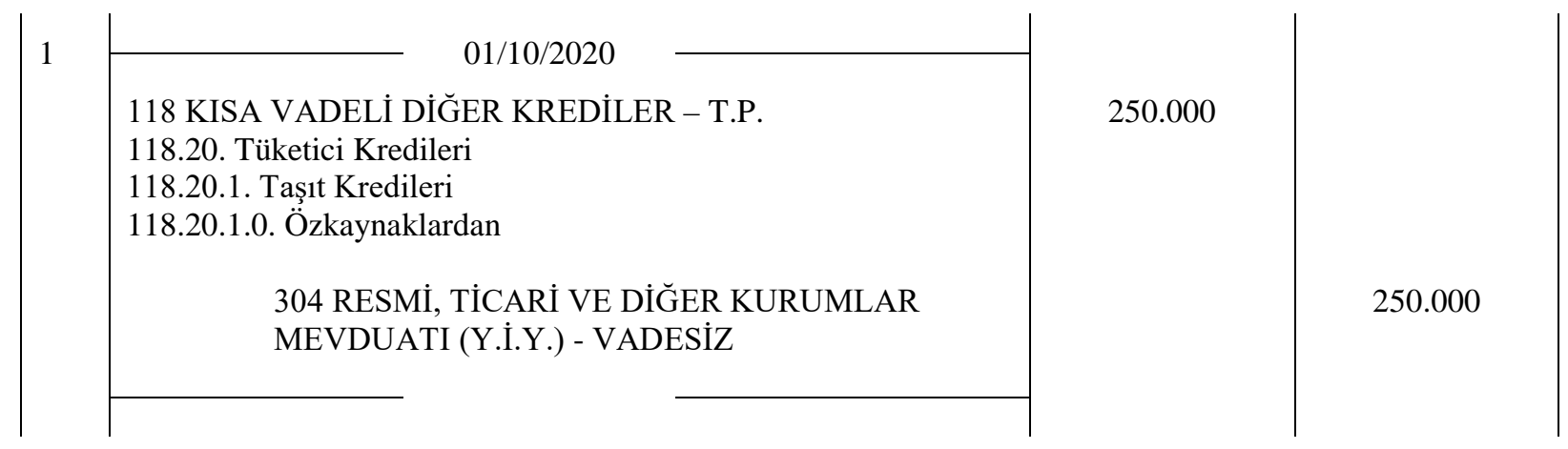

Bu kayıtla birlikte, satıcı mal bedelini almış olacak ve varlığın müşteriye transferini gerçekleştirecektir. Müşteri (alıcı) de varlığı teslim alacak ve bu aşamadan sonra belirtilen tarihler itibarıyla bankaya taksit ödemelerini gerçekleştirecektir. Banka ilk taksit günü geldiğinde öncelikle aşağıdaki gibi bir kayıt yapacaktır.

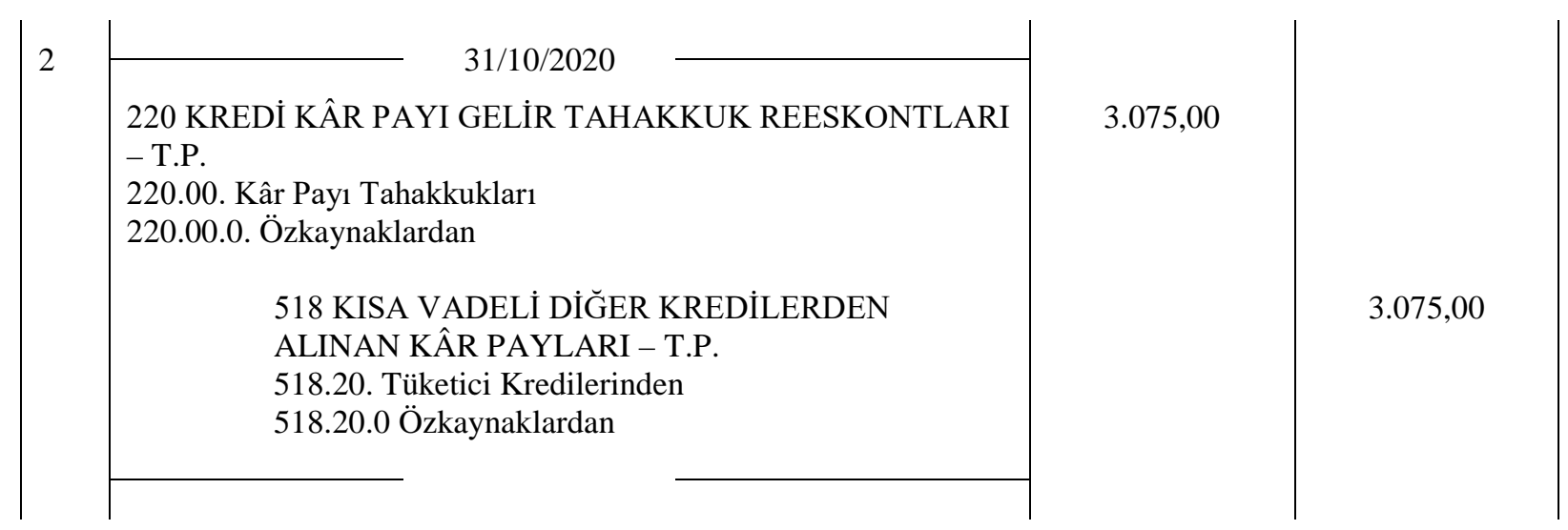

Yukarıdaki kayıtta 3.075,00 TL örnekte verilen tablonun birinci satırından alınmıştır. Aynı şekilde tablonun birinci satırından hareketle banka ilk taksit ödemesine ilişkin aşağıdaki tahsil kaydını yapacaktır. 


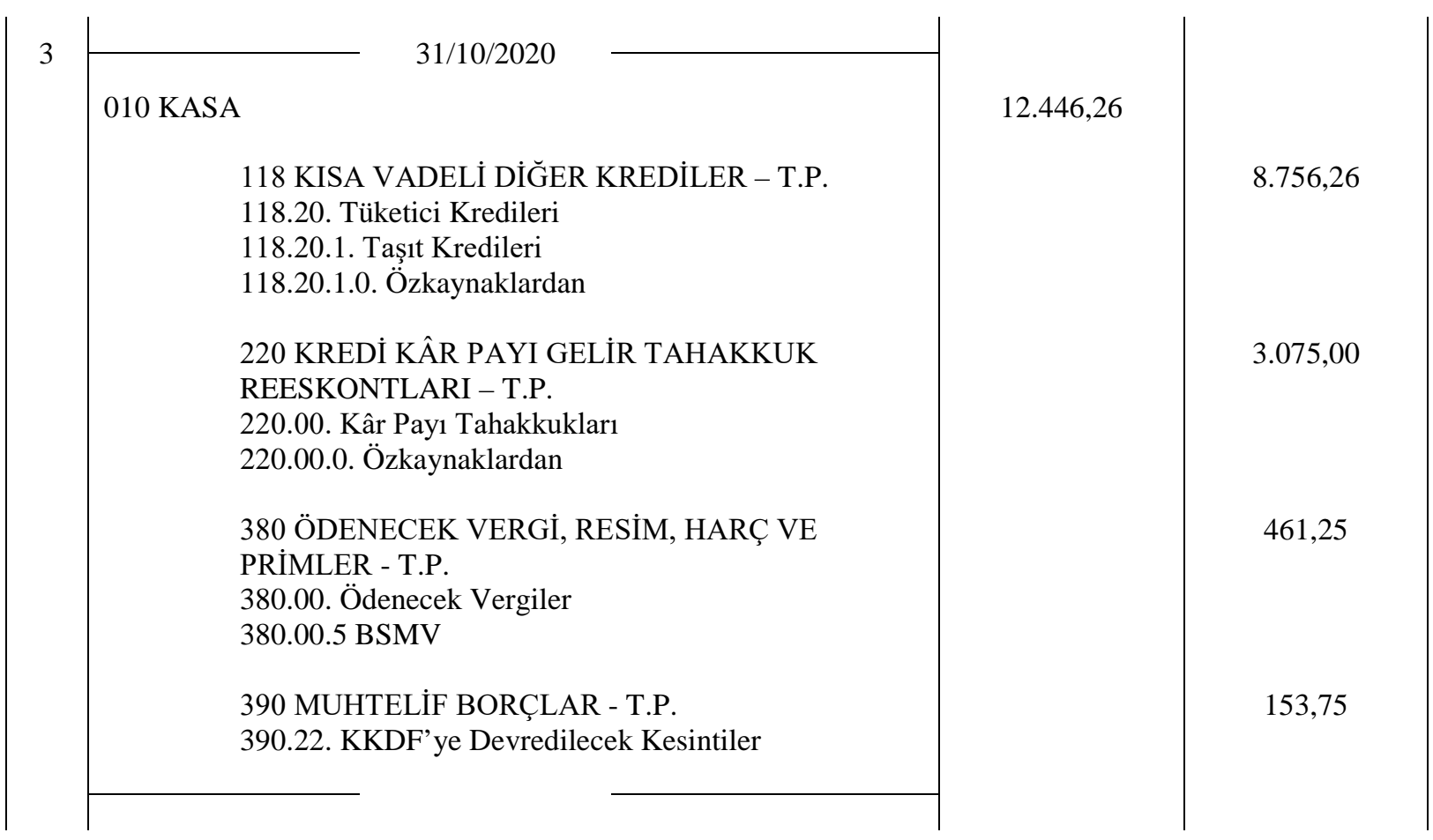

İkinci ve üçüncü kayıtlar sonraki izleyen her ayın sonunda aynen tekrar edecektir. Buna göre katılım bankası tarafından Kasım ayında 4 ve 5 ile Aralık ayında 6 ve 7. kayıtların yapıldığı varsayılarak 31.12.2020 tarihi geldiğinde defterikebir hesaplarının durumu aşağıdaki gibi olacaktır.

\begin{tabular}{cc|cc}
\multicolumn{4}{c}{118 KISA VADELİ DİĞER } \\
B & \multicolumn{2}{c}{ KREDİLER } & A \\
\hline$(1)$ & 250.000 & $8.756,26$ & $(3)$ \\
& & $8.885,50$ & $(4)$ \\
& & $9.016,65$ & $(6)$ \\
\hline & 250.000 & $26.658,41$ &
\end{tabular}

\begin{tabular}{cc|cc}
\multicolumn{4}{c}{ 220 KREDİ KAR PAYI GELİR } \\
B & TAHAKKUK REESONTLARI & A \\
\hline$(2)$ & $3.075,00$ & $3.075,00$ & $(3)$ \\
$(4)$ & $2.967,30$ & $2.967,30$ & $(5)$ \\
$(6)$ & $2.858,01$ & $2.858,01$ & $(7)$ \\
\hline & $8.900,31$ & $8.900,31$ &
\end{tabular}

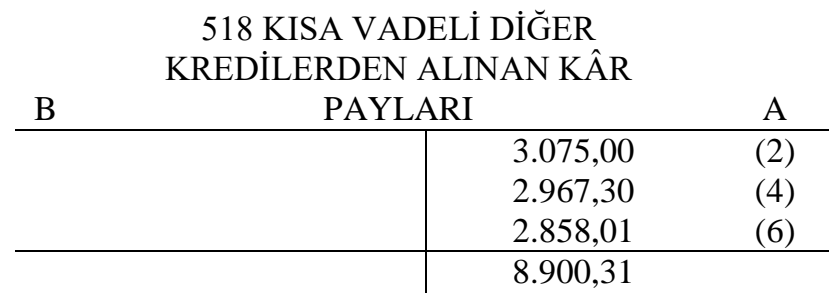

Katılım bankasının murabaha finansmanı vade boyunca dönem sonlarında düzenlenecek olan gelir tablosu (kârın dönemler itibarıyla dağılımı) ve bilançoları (finansal durum tabloları) aşağıdaki gibi olacaktır. 


\begin{tabular}{|c|c|c|}
\hline $\begin{array}{c}\text { FINANSAL TABLO DÜZENLEME } \\
\text { TARİHLERİ }\end{array}$ & $\begin{array}{l}\text { FİNANSAL DURUM TABLOSU } \\
\text { (BILANÇO) } \\
\text { Krediler ve Alacaklar (Net) }\end{array}$ & $\begin{array}{c}\text { GELİR TABLOSU } \\
\text { Kredilerden Alınan Kâr } \\
\text { Payları }\end{array}$ \\
\hline $31 / 12 / 2020$ & $214.191,85$ & $8.900,31$ \\
\hline $31 / 12 / 2021$ & $104.177,97$ & $25.159,58$ \\
\hline $31 / 12 / 2022$ & 0,00 & $6.532,08$ \\
\hline Toplam & & 40.591,97 \\
\hline
\end{tabular}

31.12.2020 tarihinde kredi ve alacaklar kalan anapara tutarı üzerinden finansal durum tablosunda yer alacaktır. 30.09.2022 tarihinde son taksit ödemesi gerçekleştiği için 31.12.2022 tarihinde düzenlenecek olan finansal durum tablosunda anapara tutarı sıfir olarak yer alacaktır.

\subsection{FFMS'ye göre Murabaha Finansmanının Muhasebe Kayıtları}

AAOIFI'ye göre murabaha finansmanı bir satış işlemidir. Zira günümüz katılım bankalarında her ne kadar resmi anlamda mal katılım bankasının mülkiyetine geçmese de müşteriyle yapılan sözleşme bir satış akdi olarak kabul edilmektedir. Bu bakımdan katılım bankası satıcıya mal bedelini ödediğinde malı satın almış olmakta ve müşterisine söz konusu malı satmış olmaktadır.

Murabaha işleminin Katılım Bankalarınca Uygulanacak Tekdüzen Hesap Planı (THP) ve İzahnamesi Hakkında Tebliğ esas alınarak AAOIFI'ye göre muhasebeleştirilmek istenmesi durumunda örneğin muhasebeleştirilmesiyle ilgili kullanılacak hesapların tamamı bulunmamaktadır. Katılım bankaları da diğer bankalar gibi esas faaliyetlerinin sadece fon toplama ve kullandırma ile sınırlandırıldığı için THP'de stoklar için herhangi bir hesap açılmamıştır. Mevcut THP incelendiğinde stoklar için açılacak en uygun hesap sınıfının "0 Dönen Değerler" olacağı öngörülmüştür. Zira stoklar FFMS 28'de olağan iş akışı içinde satılmak üzere üretilmekte olan veya elde tutulan varlık olarak tanımlanmıştır. Olağan iş akışından kasıt olağan faaliyet döngüsüdür. Dönen Değerler hesap sınıfında en son 050/051 koduyla defterikebir hesabı açılmıştır. Dolayısıyla 060 ve sonrası için Stoklar adı altında katılım bankacılığına özgü aşağıdaki gibi bir defterikebir hesabı oluşturulabilir.

070 STOKLAR - T.P.

070.10. Murabaha Konusu Varlıklar

070.10.1. Taşıtlar

070.10.1.0. Özkaynaklardan

Murabaha işlemlerinden alacakların izlenmesinde THP'deki aşağıdaki hesaplar kullanılabilir. Ancak FFMS 28 paraf. 8'de murabaha alacaklarının brüt tutarları yani vadeli tutarları üzerinden takip edileceği belirtilmektedir. Bununla birlikte THP'de kredilerin izlenmesinde kullanılan hesapların kredinin anaparası üzerinden izlenecek şekilde oluşturulduğu görülmektedir. Katılım bankası tarafından kullandırılan murabaha finansmanından doğan alacaklar brüt tutarları üzerinden "118 Kısa Vadeli Diğer Krediler" hesabına kaydedilmesi durumunda, bu hesabın netleştirilmesi için defterikebir düzeyinde "190 Ertelenmiş Kârlar (-)" adıyla düzenleyici bir hesap açılarak ertelenmiş kâr ayrıca izlenebilir. 


\section{KISA VADELİ DİĞER KREDİLER}

\subsection{Tüketici Kredileri}

118.20.1. Taşıt Kredileri

118.20.1.0 Özkaynaklardan

190 ERTELENMİŞ KÂRLAR (-)

190.18. Tüketici Kredileri

\subsubsection{Taşıt Kredileri}

FFMS 28'e göre stoklar başlangıçta maliyet değeri üzerinden finansal tablolara yansitılır. Stok maliyeti tüm satın alma maliyetleri ile stokun mevcut konumuna ve durumuna getirilmesi sırasında ortaya çıkan diğer maliyetleri kapsar. Dolayısıyla, örnekte katılım bankası araç bedeli olan 250.000 TL'yi satıcıya ödediğinde söz konusu malı stoklarında göstermek üzere aşağıdaki kaydı yapacaktır.

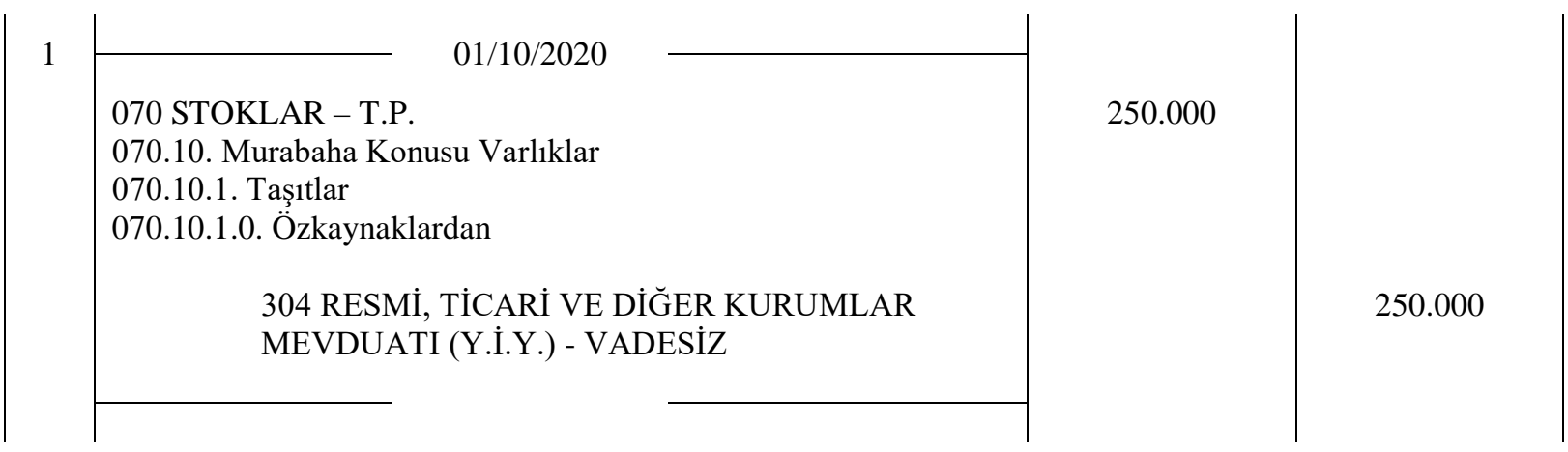

Stokların finansal tablo dışı bırakılması ilke olarak söz konusu varlıktan faizsiz finans kuruluşuna gelecekte ekonomik fayda akışının beklenmemesi durumunda gerçekleşir. Katılım bankası satış yoluyla stokun kontrolünü alıcıya devrettiğinde söz konusu stoku finansal tablo dışı bırakabilir. Murabaha işleminden katılım bankası lehine doğan alacaklar ve hasılat murabaha ya da vadeli satış sözleşmesi kapsamında söz konusu stok satıldığında itibari değeri (brüt tutar ya da fatura tutarı) üzerinden finansal tablolara alınır. Katılım bankası müşteriyle murabaha finansmanı sözleşmesini düzenlediğinde malın mülkiyetini müşteriye devretmiş ve böylece alacak da doğmuş olacaktır. Katılım bankası bu işlemi gerçekleştirdiğinde aşağıdaki kaydı yapacaktır. 

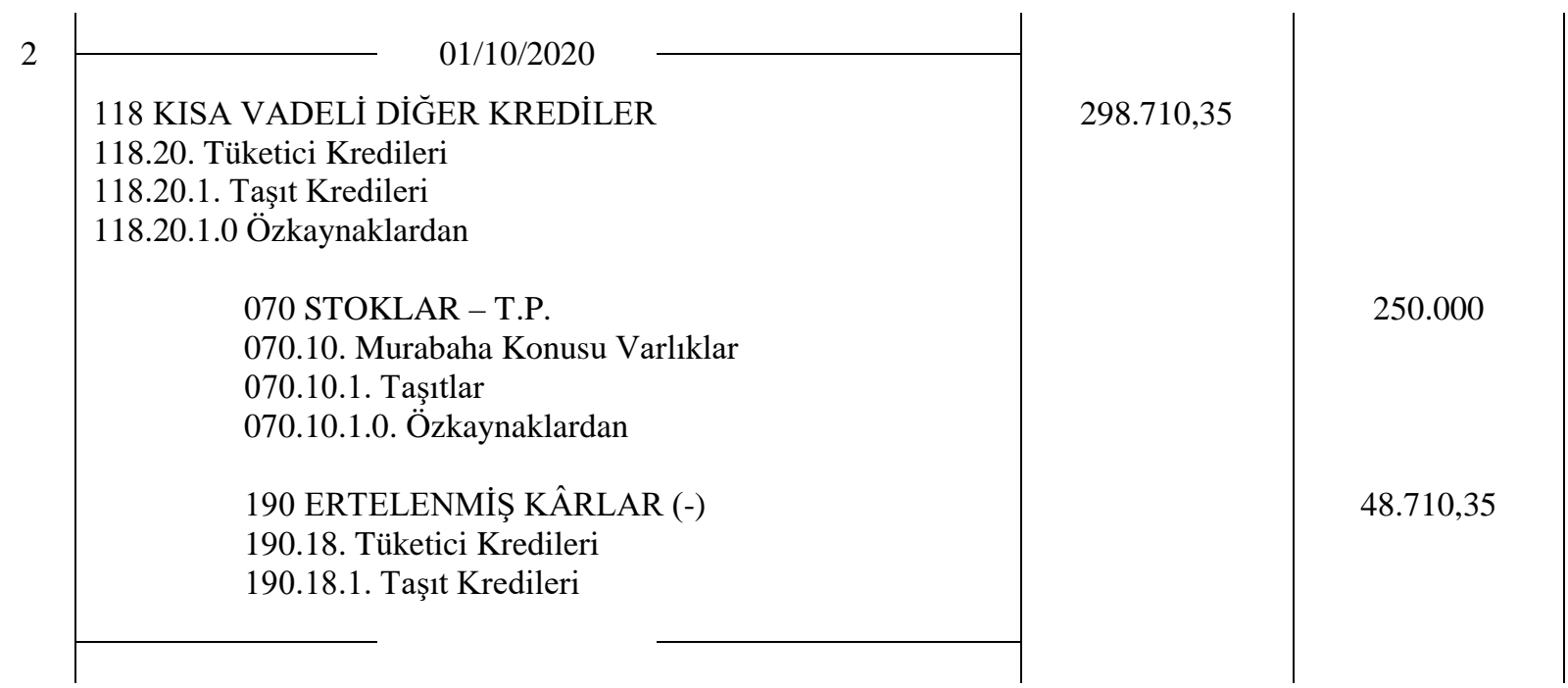

Yukarıdaki kayıtta 250.000 TL ödenerek satın alınan Murabaha Konusu Varlık murabaha finansmanı çerçevesinde müşteriye 1.3.2020 tarihinde 24 ay vadeyle 298.710,35 TL'ye satılmıştır. FFMS 28'e göre vadeli murabahada ya da diğer vadeli satışta finansal tablolara alınan hasılat ile satışların maliyeti arasındaki fark ertelenmiş kâr olarak ifade edilir. Ertelenmiş kâr ilgili alacakları düzenleyici bir varlık hesabı olarak bir ertelenmiş kâr hesabında izlenir. Orijinal vadesi 12 aydan uzun olan; taksitler hâlinde ya da vade sonunda defaten ödeme yapılacak işlemlerde, kârın zamana orantılı olarak itfa edilmesinde başvurulacak uygun yöntem, işlemdeki zımni kârı esas alan etkin kâr yöntemidir. Katılım bankası 31/03/2020 tarihi geldiğinde, ödeme planının birinci satırından hareketle öncelikle aşağıdaki gibi bir kâr tahakkuk kaydı yapacaktır.

3

190 ERTELENMIŞ KÂRLAR (-)

190.18. Tüketici Kredileri

190.18.1. Taşıt Kredileri

518 KISA VADELİ DİĞER KREDİLERDEN

ALINAN KÂR PAYLARI - T.P.

518.20. Tüketici Kredilerinden

518.20.0. Özkaynaklardan

380 ÖDENECEK VERGİ, RESIM, HARÇ VE

PRIMLER

380.00. Ödenecek Vergiler

380.00.5. BSMV

390 MUHTELIF BORÇLAR

390.22. KKDF'ye Devredilecek Kesintiler
$3.075,00$

461,25

153,75 
Yukarıdaki kayıtta 3.690,00 TL örnekte verilen tablonun birinci satırından alınmıştır. Bu tutara BSMV ve KKDF dahildir. Aynı şekilde tablonun birinci satırından hareketle banka ilk taksit ödemesine ilişkin aşağıdaki tahsil kaydını yapacaktır.
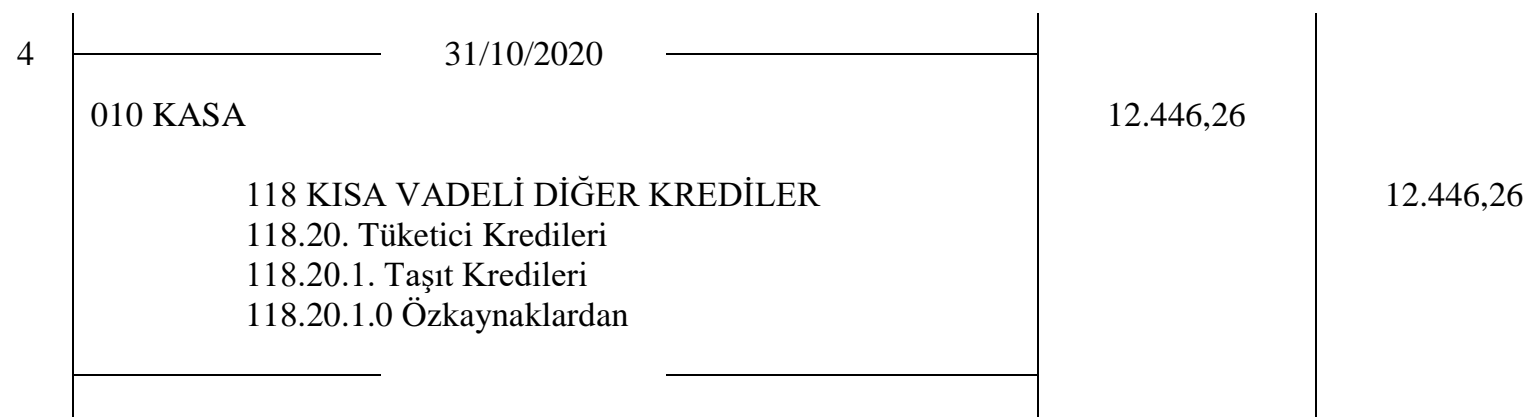

Üçüncü ve dördüncü kayıtlar sonraki izleyen her ayın sonunda aynen tekrar edecektir. Buna göre katılım bankası tarafından Kasım ayında 5 ve 6 ile Aralık ayındaki 7 ve 8 . kayıtların yapıldığı varsayılarak 31.12.2020 tarihi geldiğinde defterikebir hesaplarının durumu aşağıdaki gibi olacaktır.

\begin{tabular}{cc|cc} 
A & 070 STOKLAR - T.P. & B \\
\hline (1) & 250.000 & 250.000 & $(2)$ \\
& & \\
\hline & 250.000 & 250.000
\end{tabular}

\begin{tabular}{cc|cc} 
A & 118 KISA VADELİ DİĞER KREDİLER & B \\
\hline$(2)$ & $298.710,35$ & $12.446,26$ & (4) \\
& & $12.446,26$ & $(6)$ \\
& & $12.446,26$ & (8) \\
\hline & $298.710,35$ & $37.338,78$ &
\end{tabular}

\begin{tabular}{cc|cc} 
A & 190 ERTELENMIŞ KÂRLAR (-) & B \\
\hline$(3)$ & $3.690,00$ & $48.710,35$ & $(2)$ \\
$(5)$ & $3.560,76$ & & \\
$(7)$ & $3.429,61$ & & \\
\hline & $10.680,37$ & $48.710,35$
\end{tabular}

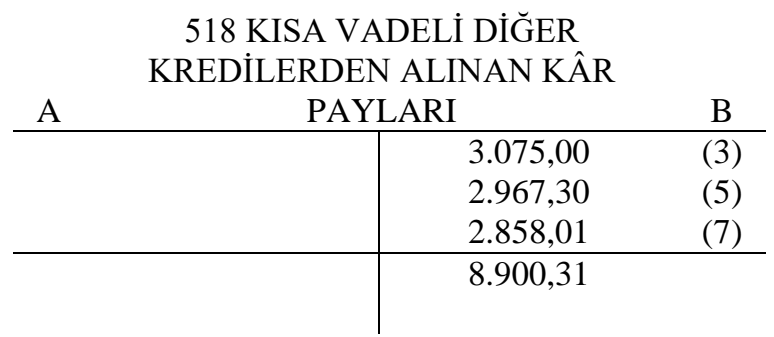

Katılım bankasının murabaha finansmanı vade boyunca dönem sonlarında düzenlenecek olan gelir tablosu (kârın dönemler itibarıyla dağılımı) ve bilançoları (finansal durum tabloları) aşağıdaki gibi olacaktır.

\begin{tabular}{lccc}
\hline & $\mathbf{3 1 / 1 2} / \mathbf{2 0 2 0}$ & $\mathbf{3 1 / 1 2 / 2 0 2 1}$ & $\mathbf{3 1 / 1 2 / 2 0 2 2}$ \\
\hline FINANSAL DURUM TABLOSU (BİLANÇO) & & & $\mathbf{0 2 , 0 0}$ \\
DÖNEN DEGERLER & $\mathbf{0 , 0 0}$ & $\mathbf{0 , 0 0}$ & 0,00 \\
070 Stoklar - T.P. & 0,00 & 0,00 & $\mathbf{0 , 0 0}$ \\
KREDİ VE ALACAKLAR (NET) & $\mathbf{2 2 3 . 3 4 1 , 5 9}$ & $\mathbf{1 0 4 . 1 7 7 , 9 7}$ & 0,00 \\
118 Kısa Vadeli Diğer Krediler (Brüt) & $261.371,57$ & $112.016,45$ & 0,00 \\
190 Ertelenmiş Kârlar (-) & $38.029,98$ & $7.838,48$ & \\
\hline GELİR TABLOSU & & & \\
518 Kısa Vadeli Diğer Kredilerden Alınan Kâr Payları & $8.900,31$ & $25.159,58$ & $6.532,08$ \\
\hline
\end{tabular}


31.12.2020 tarihinde kredi ve alacaklar kalan anapara tutarı (net alacaklar) üzerinden finansal durum tablosunda yer alacaktır. 30.09.2022 tarihinde son taksit ödemesi gerçekleştiği için 31.12.2022 tarihinde düzenlenecek olan finansal durum tablosunda anapara tutarı sıfir olarak yer alacaktır.

\section{SONUÇ VE ÖNERILER}

Murabaha finansmanı faizsiz bankacıllğın en sık kullandığı fon kullandırma yöntemlerinden biridir. Bu yöntemde müşteri bankaya gelerek belirli bir mal veya hizmeti satın alacağını belirtir. Banka talep edilen malı peşin olarak satın alır ve söz konusu müşteriye taksitli olarak satar. Murabaha işlemi alışverişe dayandığı için İslam alimleri arasındaki genel görüş meşru olduğu yönündedir. Bu şekilde değerlendirilmesinin nedeni bankanın talep edilen malı önce kendisinin satın alıp mülkiyetine geçirmesi, daha sonra bunu müşteriye satması nedeniyledir. Şayet malın mülkiyeti bankaya geçmeden, ilk satıcıdan doğrudan müşteriye geçecek olması halinde yapılan işlem bir kredi işlemidir ki bu durumda faiz devreye girer ve işlem meşruiyetini kaybeder.

Murabaha işleminin muhasebe ve raporlama işlemi Türkiye de dahil Uluslararası Muhasebe Standartları Kurumu (IASB) tarafından yayınlanan IFRS/IAS'ın uygulandığı ülkelerde bu standartlara göre yapılmaktadır. Türkiye'de TFRS/TMS olarak bilinen bu standartlar orijinalinden aynen Türkçeye çevrilerek Türkiye'de uygulanmaktadır. Bu standartlarda murabaha işlemiyle ilgili herhangi bir düzenleme bulunmamaktadır. TMS'lerde özün önceliği kavramı geçerlidir. Bu kavrama göre işlemlerin hukuki yönleri değil, özü dikkate alınmalıdır. Buna göre murabaha işlemi özünde bir kredi kullandırma işlemidir. Dolayısıyla TMS'ler açısından murabaha işlemi bir alışveriş işlemi değil bir kredi işlemi olarak değerlendirilmektedir. Zira murabaha işleminde bankanın rolü esasen finansörlüktür. 2005 yılına kadar Türkiye'de murabaha işlemlerinde katılım bankaları malı ilk satıcıdan aldıklarında faturayı kendi adlarına düzenletmekte, malı müş̧eriye satarken de müşteriye fatura kesmek durumundaydılar. Bu şekilde KDV de söz konusu olmaktaydı. Maliyetlerin ve prosedürlerin çok olması, katılım bankalarının geleneksel bankalar karşısında rekabet yeteneğini zayıf düşürdüğü için, Vergi Usul Kanununun (VUK) 204'üncü maddesinde 5228 sayılı Kanunla 31.07.2004 tarihinden itibaren geçerli olmak üzere yapılan düzenlemeyle fatura kesme yükümlülüğü kaldırılmıştır. Böylece bu tür işlemlerde murabaha konusu mallar, banka mülkiyetine geçmeden, doğrudan doğruya müşteriye geçmeye başlamıştır. $\mathrm{Bu}$ bakımdan TMS'ye göre bu işlem bir kredi kullandırma işlemi gibi değerlendirilmektedir.

AAOIFI, murabaha işlemi ile ilgili spesifik olarak standart düzenleyen uluslararası bir kuruluştur. AAOIFI'nin bu konuyla ilgili standardı Türkiye'de KGK tarafından "FFMS 28 Murabaha ve Diğer Vadeli Satı̧̧lar" adıyla yayınlamıştır. Bu standarda göre murabaha konusu mal müşteriye satılana kadar bankanın aktifinde görünmektedir. Zira AAOIFI standartlarında özün önceliği kavramının yanında işlemlerin hukuki yönleri de dikkate alınmaktadır. Her ne kadar Türkiye'de gerek banka ile ilk satıcı arasında gerekse de banka ile müşteri arasında fatura işlemi düzenlenmese de taraflar arasında yapılan akit bir satış sözleşmesi olarak sayılmaktadır. Dolayısıyla bu sözleşmeler esas alınarak söz konusu işlemler hukuki yönden AAOIFI açısından satış işlemi olarak değerlendirilmesi için yeterlidir.

Sonuç olarak murabaha işlemi TMS'ye göre bir kredi kullandırma işlemiyken, FFMS'ye göre bir satış işlemidir. Dolayısıyla her iki kurum açısından murabaha işleminin 
finansal durum tablosunda ve gelir tablosunda birtakım farklılıklar ortaya çıkmaktadır. $\mathrm{Bu}$ farklılıklardan en öne çıkanı stoklar konusunda yaşanmaktadır. FFMS'ye göre katılım bankasının finansal durum tablosunda murabaha konusu varlıklar satılana kadar stok olarak raporlanması gerekmektedir. Bir diğer önemli farklılık ise murabaha alacaklarının brüt tutarları üzerinden izlenmesi noktasında yaşanmaktadır. Geliştirilen örnekte bu durumlar göz önüne alınmış ve gerekli önerilerde bulunulmuştur.

\section{KAYNAKLAR}

AAOIFI (2015), Faizsiz Finans Standartları, Faizsiz Finans Standardı 8: Murabaha, Türkiye Katılım Bankaları Birliği (TKBB) Yayınları, İstanbul.

Antepli, Ali (2020), “TMS-23 Borçlanma Maliyetleri Standardı; Murabaha Sukuku'nun Muhasebeleştirilmesi”, Muhasebe ve Vergi Uygulamaları Dergisi, Cilt 13, Sayı 2, Ocak 2020, ss.337-351.

Aydoğmuş, Türkan (2019), Murabaha işlemlerinin TFRS ve İslami finansal kuruluşlar muhasebe standartları kapsamında değerlendirilmesi: Albaraka Türk Örneği, Yayınlanmamış Yüksek Lisans Tezi, Sivas Cumhuriyet Üniversitesi.

Bankacılık Düzenleme ve Denetleme Kurumu (BDDK), Katılım Bankalarınca Uygulanacak Tekdüzen Hesap Planı ve İzahnamesi Hakkında Tebliğ, 26.01.2007 tarihli ve 26415 Mükerrer sayılı Resmi Gazete.

Bankacılık Düzenleme ve Denetleme (BDDK), Bankaların Muhasebe Uygulamalarına ve Belgelerin Saklanmasına İlişkin Usul ve Esaslar hakkında Yönetmelik, 01.11.2006 tarihli ve 26333 sayılı Resmî Gazete.

Cebeci, İsmail (2010), "Modern İslam İktisadı Literatüründe Murabaha Tartışmaları”, Yayımlanmamış Doktora Tezi, İstanbul Marmara Üniversitesi.

Çebi, Asım - Ünkaya, Gülümser (2018), "Finansman Modeli Olarak Murabaha Sukuk: Türkiye'deki Uygulaması Ve Muhasebeleştirilmesi”, İstanbul Aydın Üniversitesi Dergisi - İAÜD - ISSN: 1309-1352, Ekim 2018 Cilt 10 Say1 4, ss.9-23.

Endelekli, Fatma (2019), Sukuk finansman modellerinden murabaha sukuk, Türkiye'de uygulaması ve muhasebeleştirilmesi, Yayınlanmamış Yüksek Lisans Tezi, İstanbul Marmara Üniversitesi.

Htay, Sheila - Salman, Syed Ahmed (2014), Financial Accounting and Reporting For Islamic Banks, IBFIM, Kuala Lumpur.

Ilter, Cenap - ElBarrad, Sherif (2012), "Murabaha-an Islamic Financial Tool and Chalanges vis a vis the International Accounting Standards”, SSRN: https://ssrn.com/abstract=2187200, pp.1-12.

Kamu Gözetim Kurumu (KGK), FFMS 28 Murabaha ve Diğer Vadeli Satışlar Standardı, 21.05.2019 tarihli ve 30780 sayılı Resmi Gazete. 
Kamu Gözetim Kurumu (KGK), TFRS 9 Finansal Araçlar Standard1, 15.01.2019 tarihli ve 26335 mükerrer sayılı Resmi Gazete.

Kamu Gözetim Kurumu (KGK), Finansal Raporlamaya İlişkin Kavramsal Çerçeve, 27.10.2018 tarihli ve 30578 sayll Resmi Gazete.

Kamu Gözetim Kurumu (KGK), TMS 2: Stoklar Standard1, 24.05.2018 tarihli ve 30430 sayılı Resmi Gazete.

Kuveyt Türk Katılım Bankası, 2017 Faaliyet Raporu, https://www.kuveytturk.com.tr/medium/document-file-1546.vsf (Erişim: 11.10.2020).

Maliye Bakanlığı, 1 Seri Nolu Muhasebe Sistemi Uygulama Genel Tebliği, 26.12.1992 tarihli ve 21447 mükerrer sayılı Resmî Gazete.

Maurer, Bill (2010). "Form versus substance: AAOIFI projects and Islamic fundamentals in the case of sukuk", Journal of Islamic Accounting and Business Research, Vol. 1 No. 1, pp. 32-41.

Özkan, Hamza (2012), Katılım Bankacılığının Klasik Bankalarla Karşılaştırılması ve Muhasebe Uygulamaları, Yayınlanmamış Yüksek Lisans Tezi, Niğde Üniversitesi.

Rosman, Romzie vd. (2016), "Financial Reporting of Murabaha Contracts: IFRS or AAOIFI Accounting Standards?”, Middle East Insights, Islamic Finance Special, pp.1-14.

Sermaye Piyasası Kurulu (SPK), Sermaye Piyasasında Finansal Raporlamaya İlişkin Esaslar Tebliği (II-14.1), 13.6.2013 tarihli ve 28676 sayılı Resmî Gazete.

Türkiye Diyanet Vakfı (TDV) İslam Ansiklopedisi (2016), https://islamansiklopedisi.org.tr/murabaha (Erişim: 11.10.2020).

Yardımcıŏglu, Mahmut - Coşkun, Sedat - Kocamaz, Hilal (2012), “Özellikli Varlık Yatırımının Finansmanında Murabaha Kredisi (Üretim Desteği) Kullanımı ve Kar Payı Ödemelerinin TMS-23'e Göre Muhasebeleştirilmesi”, Kahramanmaraş Sütçü İmam Üniversitesi İktisadi ve İdari Bilimler Fakültesi Dergisi, Cilt 2, Sayı 2, Ocak 2012, ss.121-129.

Zarfi, Adil (2019), "Murabahah Accounting for Participatory Banks in Morocco: Linking Bank Al Maghrib Accounting Scheme to AAOIFI Standard”, The Journal of Islamic Finance Accountancy (JOIFA), Cilt 3, Sayı 1/2019, pp.23-32.

5228 Sayılı Bazı Kanunlarda ve 178 Sayılı Kanun Hükmünde Kararnamede Değişiklik Yapılması Hakkında Kanun, 31.07.2004 tarihli ve 25539 sayılı Resmi Gazete.

5411 sayılı Bankacılık Kanunu, 1.11.2005 tarihli ve 25983 Mükerrer sayılı Resmi Gazete. 